\title{
Paleozoic ophiolites in the Variscan suture of Galicia (northwest Spain): Distribution, characteristics, and meaning
}

\author{
Ricardo Arenas* \\ Departamento de Petrología y Geoquímica, Universidad Complutense, 28040 Madrid, Spain \\ José R. Martínez Catalán \\ Departamento de Geología, Universidad de Salamanca, 37008 Salamanca, Spain \\ Sonia Sánchez Martínez \\ Departamento de Petrología y Geoquímica, Universidad Complutense, 28040 Madrid, Spain \\ Florentino Díaz García \\ Departamento de Geología, Universidad de Oviedo, 33005 Oviedo, Spain \\ Jacobo Abati \\ Javier Fernández-Suárez \\ Pilar Andonaegui \\ Departamento de Petrología y Geoquímica, Universidad Complutense, 28040 Madrid, Spain \\ Juan Gómez-Barreiro \\ Departamento de Geología, Universidad de Salamanca, 37008 Salamanca, Spain
}

\begin{abstract}
Allochthonous ophiolitic units in the northwestern Iberian Massif are remnants of peri-Gondwanan Paleozoic oceans sandwiched among other exotic terranes of continental and volcanic-arc derivation. All these terranes define an intricate suture zone that marks the convergence and collision between Laurussia and Gondwana. The suture is defined by three different ophiolitic ensembles: upper ophiolitic units, lower ophiolitic units, and the Somozas mélange. The lower ophiolitic units were derived from an alternation of basalts and sediments intruded by gabbros and scarce granitoids, and they formed during the opening of a marginal basin, the Galician ocean, during Late Cambrian to Early Ordovician time. This ocean was created as a back arc by the severance of a volcanic arc that had developed at the northern margin of Gondwana and formed part of the Rheic oceanic realm. The upper ophiolitic units formed during the Early Devonian from intraoceanic subduction in the early Paleozoic lithosphere of the Rheic Ocean. These suprasubduction ophiolites were formed just before the ocean closed, preceding the collision between Gondwana and Laurussia. The Somozas mélange appears in an anomalous position at the base of the Cabo Ortegal Complex. The ophiolites involved in this tectonic mélange represent an imbricate of highly dismembered oceanic lithosphere, slivers of subducted outer edge of the Gondwanan continental margin, and Paleozoic metasediments of the northern

*arenas@geo.ucm.es
\end{abstract}




\section{Gondwanan platform. The ophiolites might either record the development of a differ- ent peri-Gondwanan oceanic domain, or they might be equivalent to any of the other ophiolitic ensembles, and their anomalous structural position is simply a consequence of complex thrusting.}

Keywords: Ophiolites, Rheic Ocean, Variscan belt.

\section{INTRODUCTION}

The Variscan belt is the European part of the large orogen that developed during the late Paleozoic as a result of the progressive collision between Laurussia and Gondwana. It is probably the longest mountain belt that developed during the last stages of the formation of Pangea, and it is currently traceable from North America across northern Africa and southwestern Europe to the Bohemian Massif in Poland and the Czech Republic in Central Europe. Parts of this orogen can also be seen in southeastern Europe, where they appear in the basement of Alpine belts (Von Raumer and Neubauer, 1993; Matte, 1995, 2001). A large exposure of the Variscan basement forms the Iberian Massif, in the western Iberian Peninsula. In Galicia and Asturias, northwest of the Iberian Massif, a long and continuous section of the Variscan belt, nearly $400 \mathrm{~km}$ wide, developed in Devonian and Carboniferous times. Deformation progressed from west to east (Dallmeyer et al., 1997), and the western parts represent the more internal domain, which includes the remnants of a complex suture zone that contains several ophiolitic units (Arenas et al., 1986). The ophiolites form part of the so-called allochthonous complexes of Galicia-Trás-os-Montes; they separate the main colliding elements and represent the remnants of the Paleozoic oceanic domains that closed during the long convergence between Laurentia-Baltica and Gondwana and their final collision.

The Galicia-Trás-os-Montes zone structurally overlies the autochthonous sequences of the Central Iberian zone. According to its original description (Farias et al., 1987; Arenas et al., 1988), the Galicia-Trás-os-Montes zone consists of two different and superimposed domains (Fig. 1): a lower assemblage represented by the schistose domain of Galicia-Trás-os-Montes, and an upper assemblage formed by the allochthonous complexes of Galicia-Trás-os-Montes.

The schistose domain is made up of Paleozoic metasediments, mostly schists and sandstones, with interbedded felsic volcanic rocks. It is limited by a basal thrust and shows an imbricate internal structure (Ribeiro, 1974; Pereira et al., 1989, 2000). Even though the character of the Paleozoic sedimentary succession in the schistose domain differs markedly from the related autochthon of the Central Iberian zone, it is still possible to make stratigraphic correlations between both domains because they record a similar Variscan tectonothermal evolution. For these reasons, the schistose domain is also known as the parautochthon (Ribeiro et al., 1990). Considering that ophiolites do not appear between the Central Iberian zone and the Galicia-Trás-os-Montes zone, there is no doubt that the schistose domain formed part of the same paleogeographic realm as the Central Iberian zone: the northern continental margin of Gondwana (Arenas et al., 1986; Martínez Catalán et al., 1999). It was displaced much less than the allochthonous complexes, but the magnitude of the actual translation of the schistose domain over the Central Iberian zone is unknown, and no palinspastic reconstruction of its position on the Gondwanan paleomargin has been attempted.

The allochthonous complexes occupy the uppermost structural position in the NW Iberian Massif (Fig. 1). They were probably thrust over the schistose domain during an early deformational stage, and, later on, the already assembled GaliciaTrás-os-Montes zone overrode the Central Iberian zone. The allochthonous complexes consist of a stack of largely displaced allochthonous units, which were part of a gigantic nappe pile that was assembled during the first stages of the Variscan collision (Ries and Shackleton, 1971). The allochthonous complexes are presently preserved as megaklippen in the cores of open synforms, and they are considered to be remnants of this pile. Their denomination is based on the distinctive tectonothermal evolution recorded in each of the allochthonous units, as well as on the very large displacements that preceded their final emplacement. The allochthonous units include ophiolitic assemblages and terranes with continental and island-arc affinities (Arenas et al., 1986; Martínez Catalán et al., 1997, 1999). The ophiolites are remnants of oceanic lithosphere that was almost completely removed in pre-Variscan and Variscan times, whereas the other units are remnants of colliding continental margins and other exotic terranes located between them. Therefore, the allochthonous complexes include a rootless Variscan suture, which has provided key data for reconstructions of the evolution of the Paleozoic peri-Gondwanan realm.

\section{THE ALLOCHTHONOUS COMPLEXES OF GALICIA}

Five allochthonous complexes exist in the northwestern Iberian Massif. Three of them are located in Galicia, northwest

Figure 1. Schematic geologic map and cross-section of the allochthonous complexes of Galicia, showing the distribution of the main allochthonous units and their structural relationships. Six different ophiolitic units can be distinguished in the Cabo Ortegal and Órdenes Complexes. These ophiolites are located below the upper units, and, with the exception of the Somozas mélange, they overlie the basal units. IP_-intermediate pressure; HP-HT_high pressure, high temperature GTMZ-Galicia-Trás-os-Montes zone; CIZ-Central Iberian zone. 

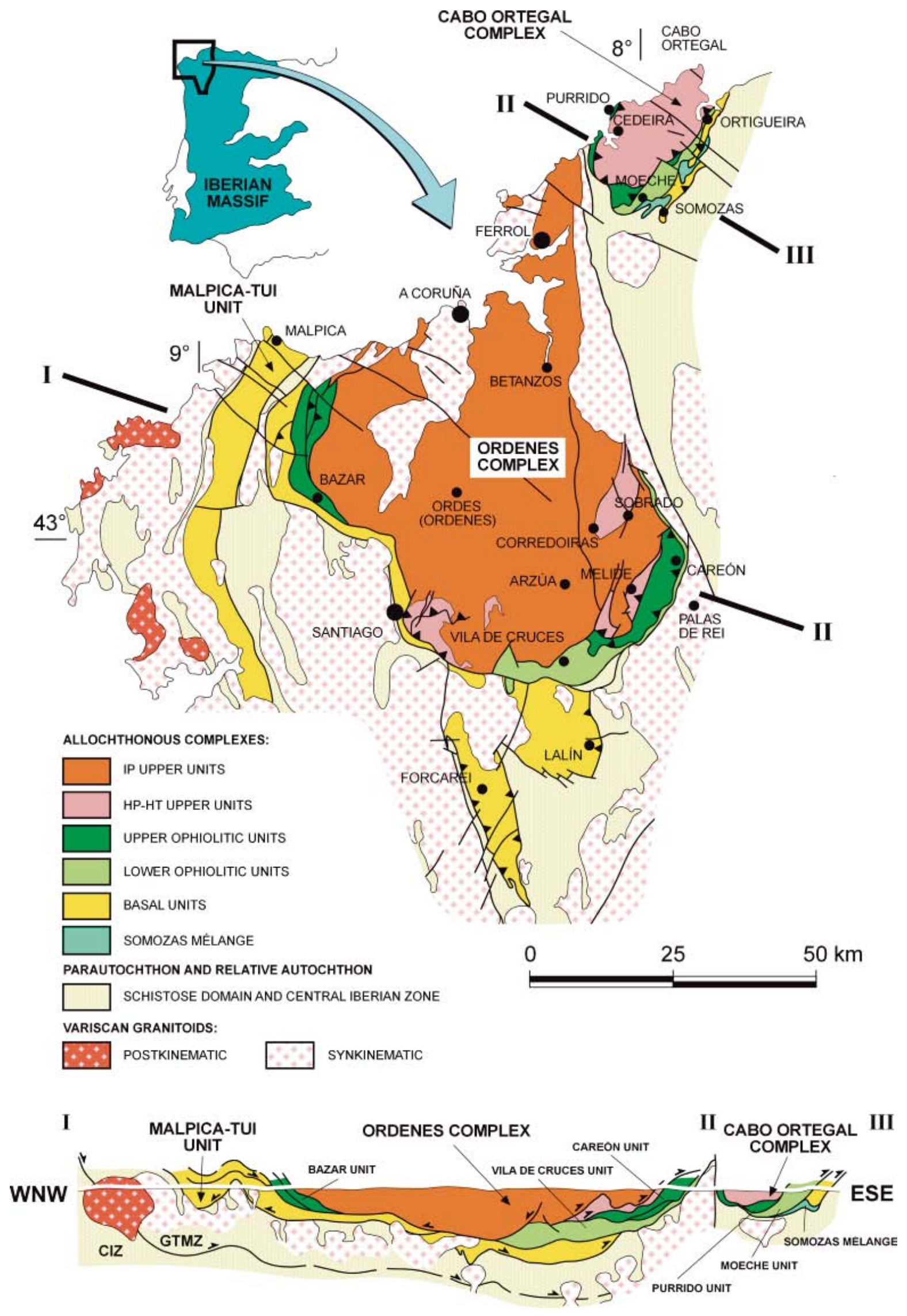
Spain (Cabo Ortegal, Órdenes, and Malpica-Tui; Fig. 1), and two are in the Portuguese region of Trás-os-Montes (Bragança and Morais). Ophiolites occur in all but Malpica-Tui, where only the basal allochthonous units have been identified. Hence, it cannot be considered as a true complex, although it is truly allochthonous, and is often named the Malpica-Tui unit. The following description introduces the Galician complexes.

The Órdenes Complex is the largest $(135 \times 75 \mathrm{~km})$ in the Galicia-Trás-os-Montes zone, and it contains representatives of nearly all the allochthonous units recognized in the NW Iberian Massif. Detailed descriptions of these units and interpretations of their meaning have been published previously (Díaz García, 1990; Abati, 2002; Castiñeiras, 2003; Martínez Catalán et al., 2002), and a synthesis of the structure and evolution of the entire complex has been presented by Arenas et al. (2000). Figure 1 shows its general structure, which is an open synform, and the distribution and tectonostratigraphic arrangement of the principal units. A more detailed view of the internal structure of the complex is presented in Martínez Catalán et al. (this volume). Different units are separated from each other by several generations of thrusts and extensional detachments, and a thrust separates the basal units from the parautochthon in the southern part of the complex, whereas late extensional detachments and strike-slip shear zones delimit its eastern and western parts.

The Cabo Ortegal Complex, located to the north (Fig. 1), is characterized by a spectacular coastal section. It has an ellipsoidal present-day shape and a small size $(30 \times 20 \mathrm{~km})$. The more outstanding aspects about the petrology and structure of this complex have been described by several authors (Vogel, 1967; Arenas, 1988; Azcárraga, 2000; Mendia, 2000; Castiñeiras, 2003; Puelles, 2003), but some additional compilations have been presented recently (Ábalos et al., 2000; Gil Ibarguchi et al., 2000; Marcos et al., 2000, 2002). The complex is separated from the schistose domain by a large thrust fault (Fig. 1), which is a relatively young structure that belongs to the out-of-sequence thrust generation described by Martínez Catalán et al. (2002). This basal thrust shows crosscutting relationships with older generations of thrusts that separate several allochthonous units in the complex. Some of the older thrusts also overprint a first generation of extensional detachments with an important metamorphic jump (Castiñeiras, 2003). In spite of its size, the Cabo Ortegal Complex includes representatives of all the units described in all of the allochthonous complexes (Fig. 1), although some of them are poorly represented when compared with their equivalents in the Órdenes Complex.

The Malpica-Tui unit is a narrow synform structure $(150 \times$ $10 \mathrm{~km}$ ) located in western Galicia (Fig. 1). Descriptions of its main characteristics have been presented by Floor (1966), Arps (1970), Llana-Fúnez (2001), Llana-Fúnez and Marcos (2002), and Rodríguez (2003). The unit consists of three lithological assemblages that are probably separated by thrusts (Gil Ibarguchi and Ortega Gironés, 1985), but the basal thrust fault is rarely preserved (Llana-Fúnez, 2001) because its present boundaries are mostly extensional and strike-slip shear zones and other faults.
The units that form the allochthonous complexes can be grouped into three main lithologic assemblages, which appear in a regular stacking order. From bottom to top, they consist of the basal, ophiolitic, and upper units (Fig. 1). The basal and upper units have lithologic signatures characteristic of both continental crust and island arcs, including forearc and back-arc domains, both in an arc setting. The ophiolitic units consist of lithologic units characteristic of oceanic domains, including marginal basins and transitional zones between continents and oceans. Moreover, the basal and ophiolitic units exhibit a relatively simple tectonothermal evolution of early Variscan to Variscan events, but the upper units are polymetamorphic assemblages where both Variscan and pre-Variscan tectonothermal events have been described. In the following sections, their main characteristics will be described, with emphasis placed on ophiolitic units, the primary objective of this contribution. The origin and evolution of all units will be discussed in the context of early Paleozoic peri-Gondwanan evolution and later Laurussia-Gondwana collision.

\section{BASAL UNITS}

These units consist of metasediments alternating with granitic orthogneisses and metabasites, which attain a maximum thickness of 3000-4000 $\mathrm{m}$ in the Malpica-Tui unit (Llana-Fúnez, 2001). The metasediments include metagraywackes, pelitic and semipelitic schists with garnet and albite-oligoclase porphyroblasts, paragneisses and migmatitic paragneisses, as well as scarce chert, black slate, calc-silicate, and quartzite lenses. It is still possible to recognize turbiditic facies in the low-grade successions (Llana-Fúnez, 2001).

The deformation is heterogeneous; it is possible to find weakly deformed metaigneous rocks surrounded by strongly deformed to mylonitic metasedimentary rocks. In little deformed turbiditic layers of the Malpica-Tui unit, Fombella Blanco (1984) described palynomorphs that suggested an Early to Middle Ordovician age. The metabasic rocks include garnet-bearing and garnet-free amphibolites, amphibolites with albite porphyroblasts, and eclogites with a variety of textures. Orthogneisses include mylonitic felsic gneisses and biotite gneisses of calc-alkaline affinity, and also alkaline and peralkaline gneisses (Floor, 1966; Montero, 1993; Rodríguez, 2003). Rb-Sr isotopic dating of some gneisses has yielded protolith ages ranging from 460 to $480 \mathrm{Ma}$ (Priem et al., 1966; Van Calsteren et al., 1979; García Garzón et al., 1981), whereas a more precise age of ca. $480 \mathrm{Ma}$ (U-Pb on zircon by thermal ionization mass spectrometry [TIMS]) has been obtained from a metagranodiorite (Santos Zalduegui, 1995). The protoliths of the peralkaline gneisses were probably the youngest because they never include mafic rocks, which are viewed as dikes and are very common in the other types of orthogneisses (Floor, 1966; Gil Ibarguchi and Ortega Gironés, 1985). Apparently, initial magmatism probably had a bimodal felsic-mafic character and was followed by another peralkaline magmatic event. According to Pin et al. (1992), alkaline and peralkaline gneisses have geochemical signatures typical of A-type 
granitoids, whereas the mafic rocks have chemical compositions of alkaline basalts. It has been suggested that Ordovician magmatism was active in the basal units during the first stages of continental rifting, although available data do not rule out a more complex evolution for this magmatism and hence for the origin of the basal units.

The basal units were affected first by a high-pressure $(P)$ metamorphic event related to subduction at the beginning of Variscan deformation. The timing of this metamorphism has been dated by Rodríguez et al. (2003) at $365-370 \mathrm{Ma}\left({ }^{40} \mathrm{Ar} /{ }^{39} \mathrm{Ar}\right)$ using white micas from eclogites, although the same authors place the beginning of subduction and the coeval eclogite metamorphic event somewhat earlier, 380-385 Ma. According to the intensity of the high- $P$ Variscan metamorphism, the basal units can be divided into two different assemblages: a lower unit containing low- to intermediate-temperature $(T)$ metamorphism, and an upper unit affected by medium- to high- $T$ metamorphism (Arenas et al., 1995, 1997; Martínez Catalán et al., 1996). Nevertheless it is clear that all these units were part of a relatively continuous and little disturbed slab of continental high- $P$ rocks (Fig. 1).

It is possible to recognize the metamorphic gradient associated with the first high- $P$ event in this slab in the Órdenes Complex: pressure and temperature increase from east to west (present coordinates). This has been interpreted by Martínez Catalán et al. (1996) to indicate a westward polarity for early Variscan subduction. This subduction developed below a mantle wedge, which was probably responsible for the thermal increase in the basal units during uplift. Heating was caused by convective heat transport from the overlying mantle, and it gave rise to an inverted metamorphic gradient (Arenas et al., 1995; Martínez Catalán et al., 1996). Data on the tectonothermal evolution of the basal units have also been presented by Gil Ibarguchi and Ortega Gironés (1985), Arenas (1988), Gil Ibarguchi (1995), Arenas et al. (1997), Rubio Pascual et al. (2002), Rodríguez (2003), and Alcock et al. (2005).

The deformational history of the basal units after the high- $P$ event is complex and has been described by Martínez Catalán et al. (1996, 1999). Exhumation occurred during continental collision, and was mainly caused by thrusting, aided by the coeval extensional detachments related to extensional collapse of the overlying part of the orogenic edifice. The evolutionary history is similar to that proposed by Platt (1986) for the dynamics of orogenic wedges.

\section{OPHIOLITIC UNITS}

Five ophiolitic units are recognized in Galicia, three in the Órdenes Complex (Vila de Cruces, Careón, and Bazar units; Fig. 1), and two in the Cabo Ortegal Complex (Moeche and Purrido units; Fig. 1). In addition, remnants of an extremely fragmented ophiolite are involved in the Somozas mélange, a complex ophiolitic and sedimentary mélange imbricated with the basal units of the Cabo Ortegal Complex (Fig. 1). The ophiolite involved in this mélange exhibits a characteristic lithological composition and a unique structural position. It includes most of the lithologies described in common ophiolites, and they are usually not penetratively deformed.

Based on their similar lithological composition and structural position beneath the upper units of the allochthonous complexes, the Bazar, Careón, and Purrido units are considered to be equivalent, and they are generally described as the upper ophiolitic units (Fig. 1). The Moeche and Vila de Cruces units underlie the upper ophiolitic units, and, based on their equivalent lithologies, similar structural position, and common tectonothermal evolution, both are correlated and described as the lower ophiolitic units (Fig. 1). The Somozas mélange contains a unique and distinctive lithological assemblage and will be described separately.

\section{Upper Ophiolitic Units}

The Careón unit is the best-preserved lithological ensemble of this group (Figs. 2 and 3). According to Díaz García et al. (1999a), it consists of a stack of three different thrust sheets, the Orosa, Careón, and Vilouriz slices (Fig. 3), which together represent an early Variscan imbricate. The Careón slice reveals a more varied lithologic association, with $500 \mathrm{~m}$ of serpentinized ultramafic rocks and some $600 \mathrm{~m}$ of gabbro. This assemblage may contain a mid-Paleozoic crust-mantle transition of oceanic lithosphere. It also contains stocks of gabbro pegmatite, diabase dikes, some wehrlite sills, and uncommon leucogabbro and leucotonalite (Fig. 3). Díaz García et al. (1999a) obtained an age of ca. $395 \mathrm{Ma}$ (U-Pb on zircon by TIMS) in a sample of quartz-bearing leucogabbro from the top of the Careón slice (Fig. 3), which they interpreted to date gabbro protolith crystallization and the age of this ophiolite. This age has been confirmed by Pin et al. (2002; U-Pb on zircon by TIMS) with another gabbro sample in the Careón slice.

The amphibolite-facies regional foliation, dated at ca. 376 Ma $\left({ }^{40} \mathrm{Ar} /{ }^{39} \mathrm{Ar}\right.$ in hornblende; Dallmeyer et al., 1997), suggests that the accretion of the ophiolitic slices took place during the Middle Devonian, although ages as old as 390 Ma (Early Devonian) have been obtained by the same method in similar units of the Cabo Ortegal and Portuguese Complexes (Peucat et al., 1990; Dallmeyer and Gil Ibarguchi, 1990; Dallmeyer et al., 1991). Pervasive shearing affected the ophiolite during accretion, transforming the mafic rocks into greenschist-facies rocks and garnet-free or garnet-bearing amphibolites characterized by an inverted metamorphic gradient that increases upward toward the ultramafic rocks of the overlying tectonic slice (Fig. 3). $P-T$ conditions of $650{ }^{\circ} \mathrm{C}$ and $11.5 \mathrm{kbar}$ have been calculated from the mineral assemblages of the garnet-bearing amphibolites (Díaz García et al., 1999a), and they provide an indication of the tectonic setting where both accretion and imbrication of the ophiolite slices took place. Moreover, spectacular centimeter-size red corundum porphyroblasts grew at some thrust contacts between the mafic and ultramafic rocks (Fig. 3). These contacts are considered metamorphic soles developed during the imbrication of hot oceanic lithosphere. 

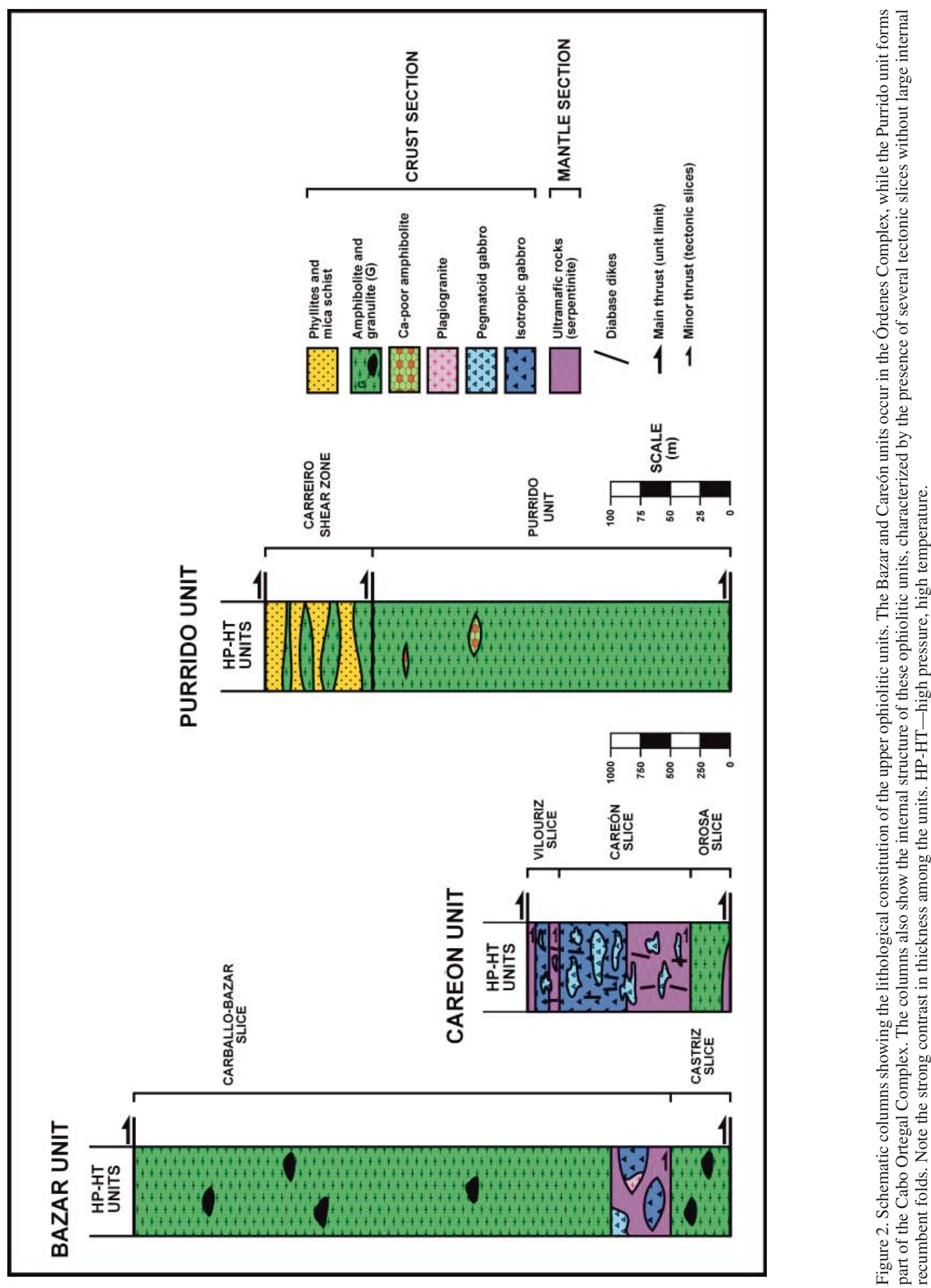


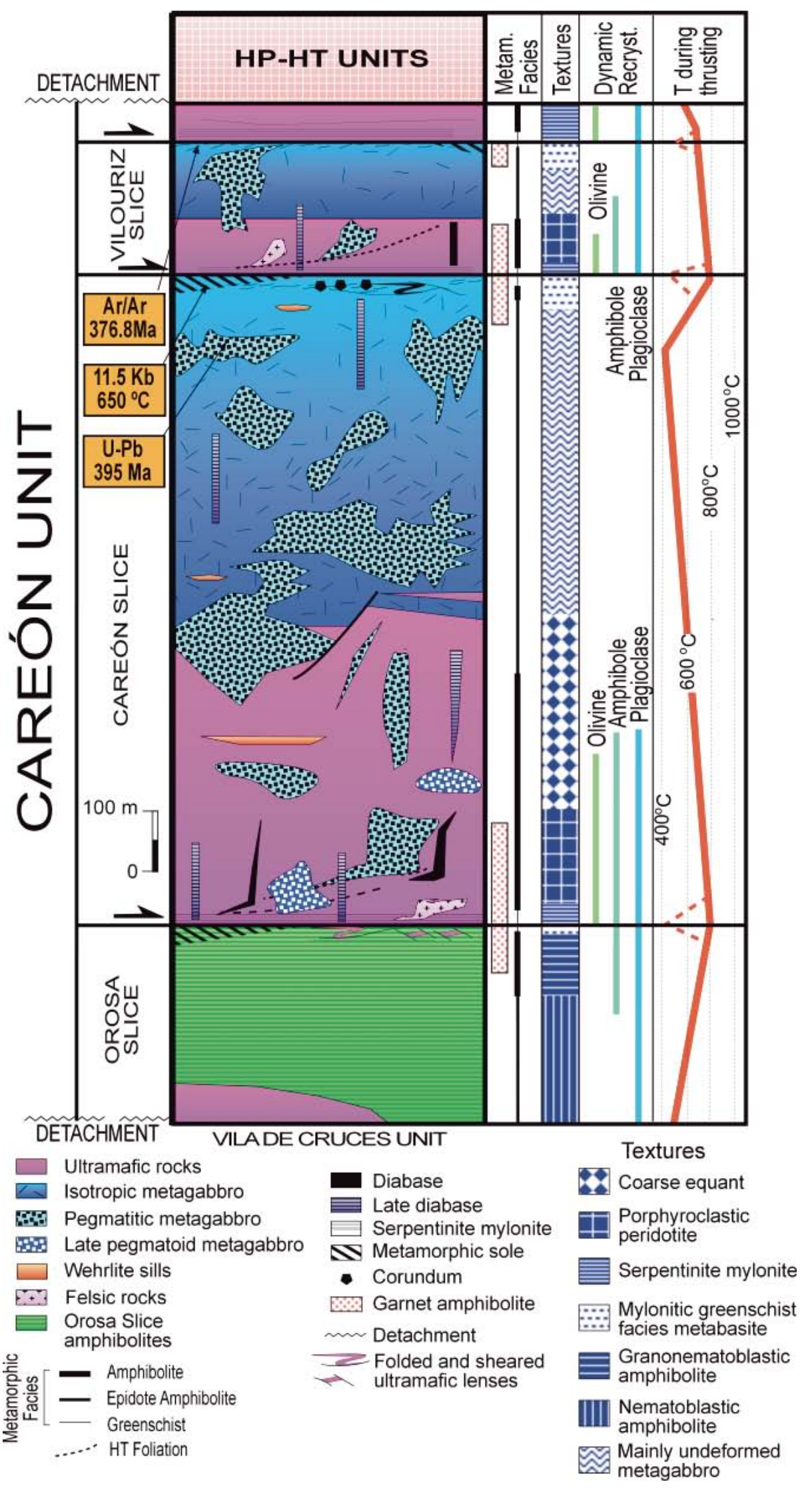

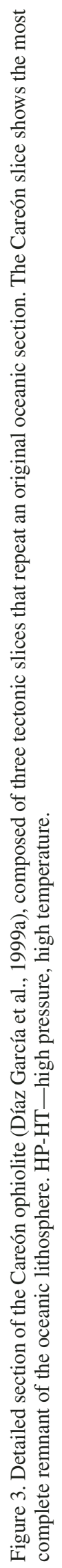


According to Díaz García et al. (1999a), the Careón unit represents one of the last portions of oceanic lithosphere formed in the peri-Gondwanan realm some 395 m.y. ago, during Late Silurian to Early Devonian times. This young oceanic lithosphere was subducted promptly below an advancing eo-Variscan accretionary wedge, preserving at least a part of its original thermal structure. Accretion and imbrication of hot ophiolitic slices can explain the steep metamorphic gradients characteristic of this unit, which have their best expression in the development of the metamorphic soles. According to Pin et al. (2002), the geochemistry of the mafic rocks of the Careón unit is characteristic of a suprasubduction zone setting. Consequently, the oceanic litho- sphere that it represents was not generated in a mid-oceanic ridge but probably in the initial stages of development of a marginal basin, or in a forearc during intraoceanic subduction.

The Purrido unit is a 300-400-m-thick sheet consisting of common amphibolite and garnet-bearing amphibolite of gabbroic origin (Vogel, 1967; Azcárraga, 2000; Figs. 2 and 4). Its lithology and thickness are similar to those of the Orosa slice in the Careón unit (Figs. 2 and 3). Its internal structure is rather monotonous, and internal folding or imbrications have not been described. A hornblende concentrate from the regional amphibolite-facies foliation yielded a ${ }^{40} \mathrm{Ar}{ }^{39} \mathrm{Ar}$ age of $391.3 \pm 6.6 \mathrm{Ma}$ (Peucat et al., 1990), which is also viewed as dating the accretion
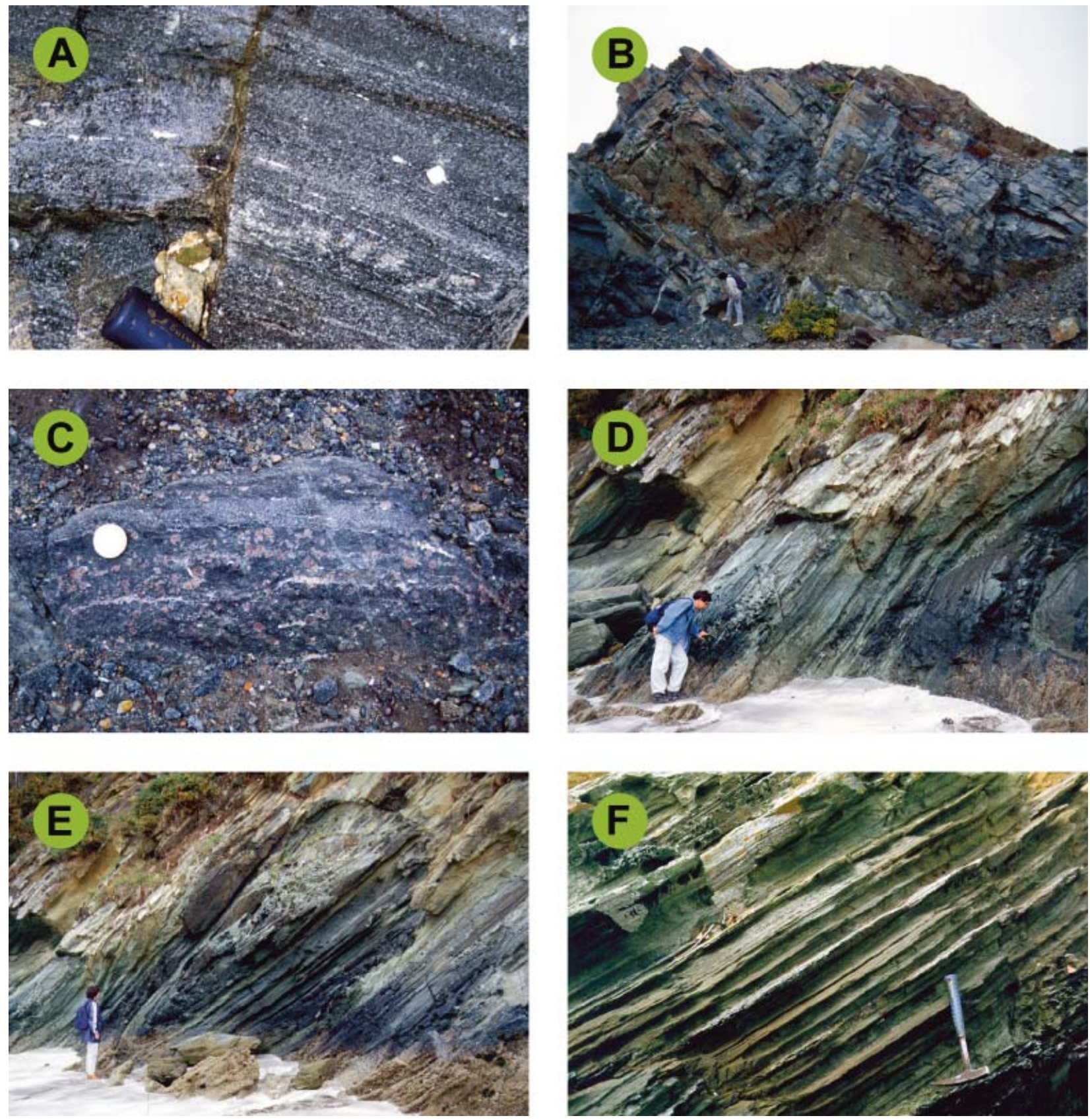
of oceanic slices. Furthermore, the geochemical characteristics of the Purrido metabasites also point to a suprasubduction zone setting (Sánchez Martínez, 2003), supporting the proposed correlation between the Purrido and Careón units.

The Bazar unit is located in the western part of the Órdenes Complex (Figs. 1 and 2). Though its internal structure is poorly known, its thickness, up to $5000 \mathrm{~m}$, and the presence of several thrust faults suggests that it is an imbricate. It is made up of monotonous metagabbroic amphibolite, with a relatively undeformed layer of gabbro, leucogabbro, pegmatoid gabbro, pyroxenite, and ultramafic rocks located toward the lower part of the unit (Díaz García, 1990; Abati, 2002; Fig. 2). The unit was affected by an early high- $T$ metamorphism, which formed mafic granulites transitional between the low- and medium- $P$ types. The origin and meaning of this high- $T$ metamorphic event are not clear, but it can be tentatively interpreted as related to subduction of very young oceanic lithosphere, culminating with subduction of a mid-ocean ridge.

\section{Lower Ophiolitic Units}

In the Órdenes Complex, the Vila de Cruces unit (Fig. 5) is a thrust sheet that may be $3500 \mathrm{~m}$ thick; it consists of variably deformed greenschist, metapelitic mica schists, and schists with porphyroblasts of albite and garnet, subordinate black chert, felsic orthogneiss, metagabbro, and serpentinite (Martínez Catalán et al., 2002). Another $700 \mathrm{~m}$ should be added below, if the ultramafic rocks of the Campo Marzo slice, separated from Vila de Cruces by a late extensional detachment, are included in this ophiolite (Martínez Catalán et al., 1996).

The pelitic schists occur as intercalations in the greenschistfacies mafic rocks and are repeated by recumbent folds in the lower part of the unit (Vila de Cruces slice) and by thrust faults in its upper part (Sampaio slice; Fig. 5). The metapelites included in the Vila de Cruces slice are low- $T$ mica schists with occasional chloritoid and albite porphyroblasts. In the Sampaio slice, the metapelitic rocks appear as medium- $T$ schists with frequent porphyroblasts of garnet and albite. In spite of the strong deformation and retrogression recorded by these schists, the earliest mineral assemblage containing garnet does not include biotite, which suggests high- $P$ and low- to intermediate- $T$ conditions during the first metamorphic event. This event preceded or was contemporaneous with development of the first generation of kilometerscale recumbent folds. A new generation of smaller overturned folds deformed the unit, developing the regional axial-planar greenschist-facies foliation. Finally, the unit was deformed by

Figure 4. Field aspects of the upper $(A-C)$ and lower (D-F) ophiolitic units in the Cabo Ortegal Complex. (A-C) Metagabbroic amphibolite and garnet amphibolite (B) from the Purrido unit. (D-F) Greenschist from the Moeche unit; the photograph in E shows one of the recumbent folds that characterizes the internal structure of this unit.
E-SE-vergent thrusts, which created the present imbricate structure (Martínez Catalán et al., 2002).

The regional foliation has been dated at 363-367 Ma $\left({ }^{40} \mathrm{Ar} /{ }^{39} \mathrm{Ar}\right.$ in muscovite concentrates from pelitic schist; Dallmeyer et al., 1997), which also establishes a minimum age for the first high- $P$ metamorphic event and for the first deformation affecting the unit. Moreover, the isotopic dating of an orthogneiss of the Vila de Cruces unit yielded and age of ca. $500 \mathrm{Ma}$ (U-Pb on zircon by TIMS; Arenas et al., 2005), which establishes a minimum age limit for generation of that lower ophiolitic unit.

In the Cabo Ortegal Complex, the 500-m-thick Moeche unit was described by Arenas (1988) as a layer of ultramylonitic greenschist. Although more strongly deformed, this unit is lithologically similar to the Vila de Cruces unit, and it occurs at an equivalent structural position (Figs. 4 and 5). The Moeche unit can be correlated with the lower part of its equivalent in the Órdenes Complex, the Vila de Cruces slice, because it does not contain schist with albite and garnet porphyroblasts. The tectonothermal evolution of the Moeche unit is also similar to that of the Vila de Cruces ophiolite, and the regional foliation has been dated here at ca. $364 \mathrm{Ma}\left({ }^{40} \mathrm{Ar} /{ }^{39} \mathrm{Ar}\right.$, whole rock in a mica schist; Dallmeyer et al., 1997).

In the lower ophiolitic units, Variscan deformation was so strong that it is generally impossible to recognize the nature of the protoliths. However, some scarce metabasites have textures suggesting a gabbroic origin. In the Vila de Cruces orthogneisses, porphyroclasts wrapped by the mylonitic foliation reveal finegrained granular textures indicative of a history that postdates hypabyssal granitoids. Most of the greenschist, by far the most abundant lithology, was probably derived from volcanic rocks (basalts), an interpretation supported by the geochemical composition of the mafic rocks, absence of plutonic textures, and the presence of interbedded schist and chert (Martínez Catalán et al., 2002). Moreover, an origin as weathered volcanic rocks may explain the strong mylonitization characteristic of many greenschists, as these rocks may show a weaker rheological behavior against deformation.

An important fact related to the origin of the lower ophiolitic units is the common occurrence of metasedimentary rocks not found in the upper ophiolitic units. This suggests an origin near an emerged domain. Furthermore, the lower ophiolites were obducted over the basal units, and some of their lithologies, like the albite-bearing schists and the orthogneisses, are rather similar. Therefore, and considering that the Vila de Cruces unit has a Late Cambrian age, it is very likely that the lower ophiolitic units were generated near the Gondwanan continental margin, represented by the basal units in the Galicia-Trás-os-Montes allochthonous complexes. In this context, these ophiolites would probably be related to the early opening of an oceanic basin in the peri-Gondwanan realm and, more specifically, to the first stages of development of a marginal basin above a subduction zone. This oceanic domain is here named the Galician ocean. Though it is not clear whether or not this basin represents the first stages in the opening of the Rheic Ocean, a relationship with this ocean can be postulated. 

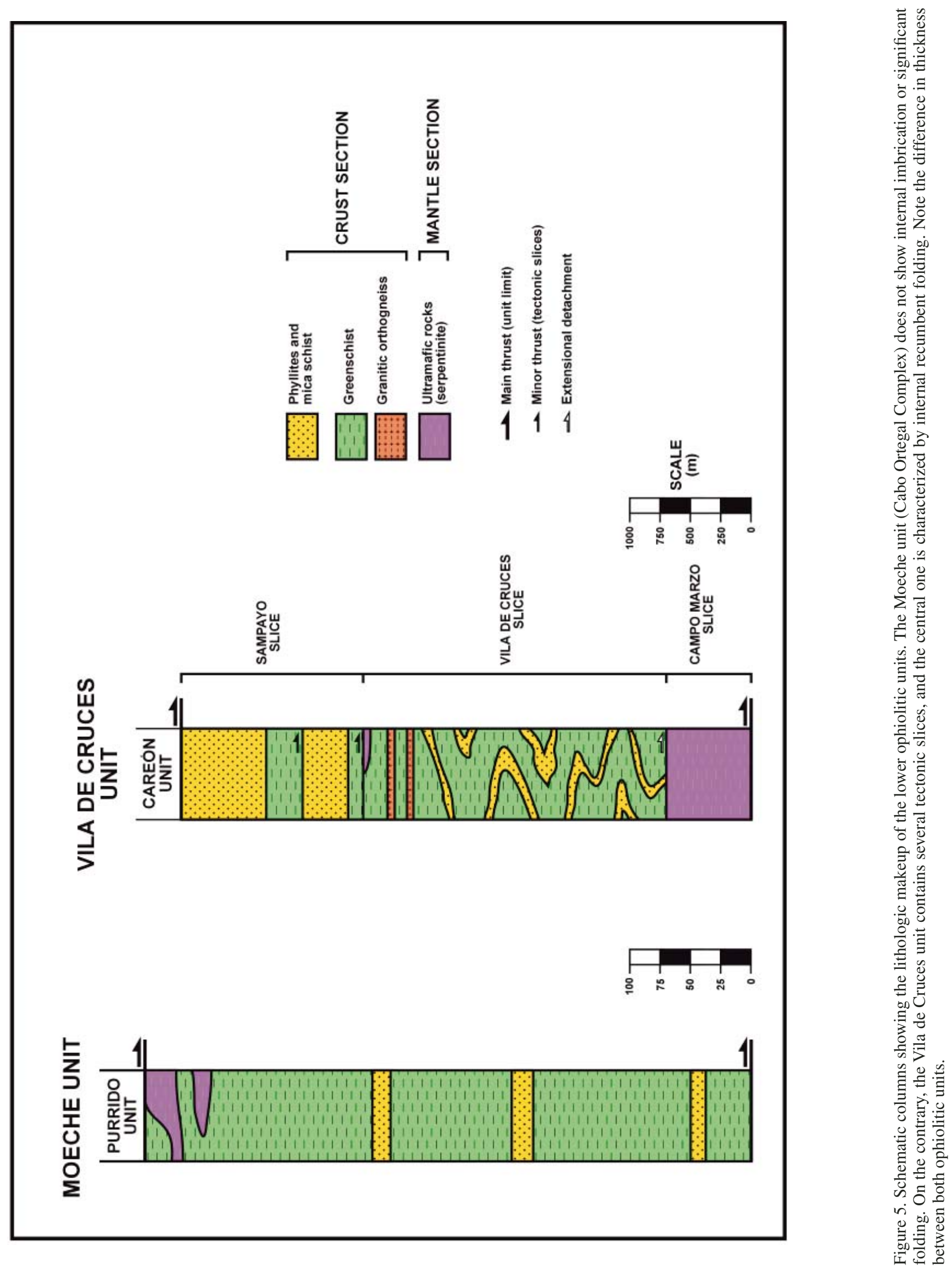
New geochemical data support this interpretation (Sánchez Martínez, 2003; Sánchez Martínez et al., this volume).

\section{Somozas Mélange}

The lithologic characteristics and structural position of the Somozas mélange were described by Arenas (1988), who also pointed out the dismembered character of the unit. Marcos et al. (2002) suggested that the internal structure of this unit is typical of a tectonic mélange. It is a 500-m-thick unit where meter- to hectometer-sized ellipsoidal tectonic blocks can be recognized (Fig. 6). The tectonic blocks include ophiolitic lithologies, metasedi- mentary rocks, and high- $T$ orthogneisses and amphibolites, all wrapped by a low- $T$, highly sheared matrix of serpentinite or phyllite. In detail, the internal structure is rather complex, and two different superimposed mélange units can be distinguished. The lower part of the mélange is mostly a sedimentary mélange, where few blocks of ophiolitic and high- $T$ rocks are distributed between sheared brownish phyllite and bluish phyllonite, with occasional sheared conglomerate, metagraywacke, and rhyolite beds. The upper part consists of typical ophiolitic mélange with few sedimentary blocks (phyllite, phyllonite, conglomerate, and marble). Some scarce high- $T$ blocks also appear in this upper part. The section in Figure 6 is typical of the upper ophiolitic

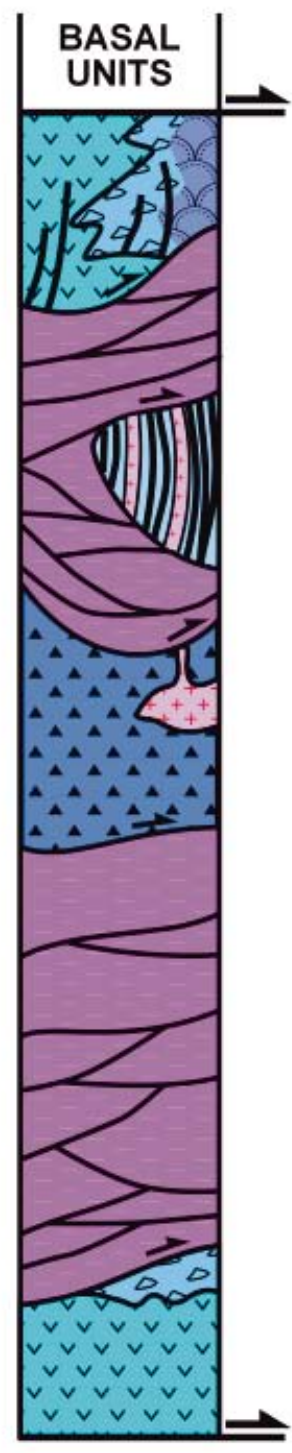

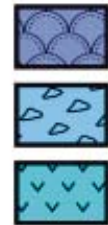

Pillow lava and pillow-breccia

Hyaloclastite

Lavas: basalt and basaltic andesite

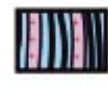

Diabase and plagiogranite dikes

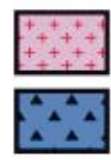

Plagiogranite

Gabbro

Ultramafic rocks

(serpentinite)

Diabase dikes

$\rightarrow$ Main thrust (unit limit)

$\rightarrow$ Minor thrust (tectonic slices)

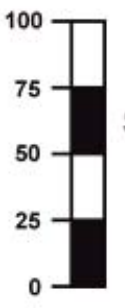

\section{SCALE}

(m)
SUBMARINE VOLCANIC ROCKS

DIKE COMPLEX

PLUTONIC SECTION

MANTLE SECTION

Figure 6. Schematic section showing the lithologic characteristics and internal structure of the ophiolitic mélange that forms part of the Somozas mélange (Cabo Ortegal Complex). 

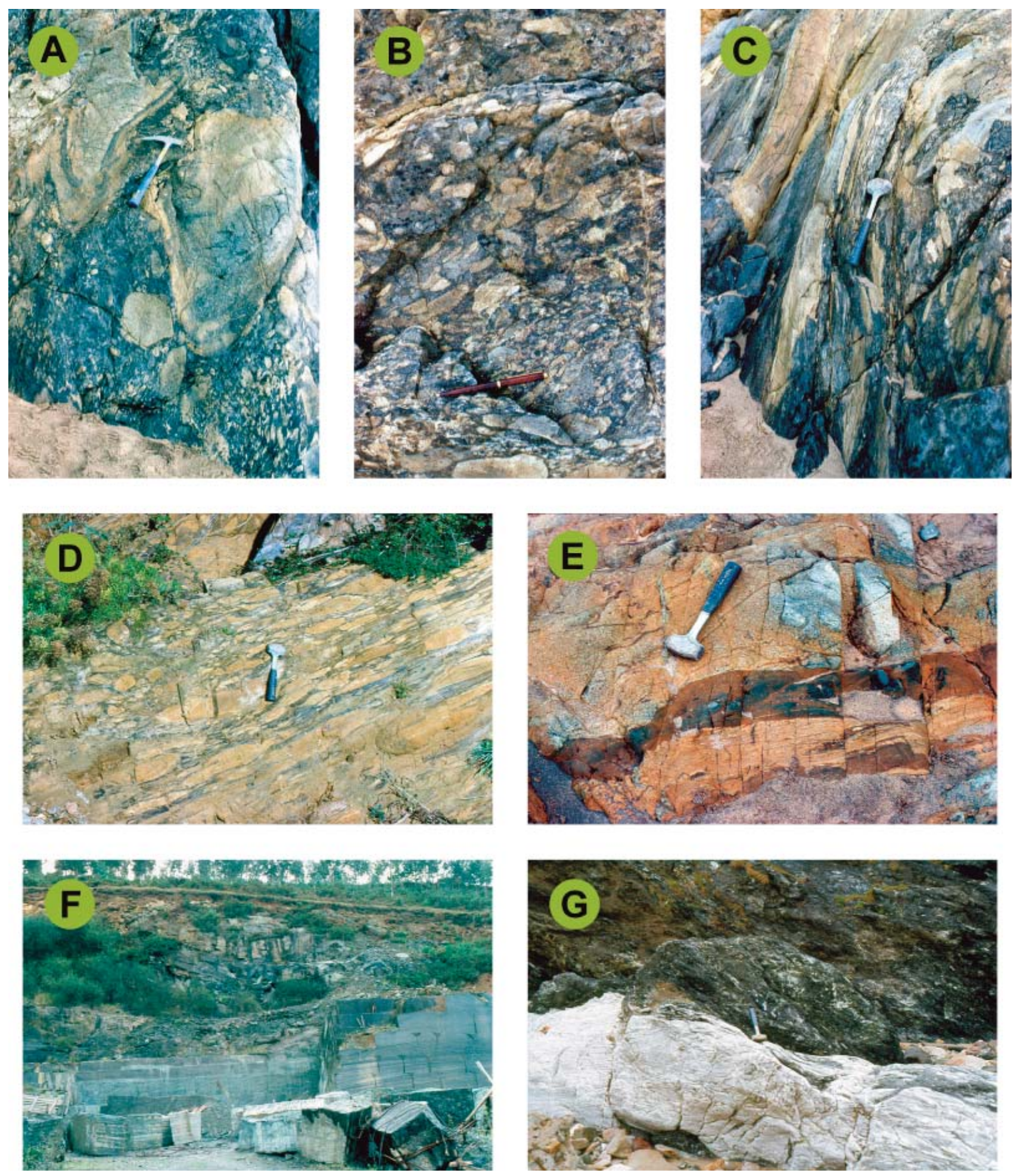

Figure 7. Field aspects in the Somozas mélange (Cabo Ortegal Complex). (A) Pillow breccia preserving large pillows. (B) Pillow breccia. (C) Sheared pillow breccia with large individual pillows. (D) Close-packed pillows. (E) Massive submarine volcanic rocks intruded by diabase dikes. (F) Imbricate of serpentinite (lower part of the quarry) and sheared conglomerate (upper part). (G) Imbricate of serpentinite and marble. 
mélange. Deformation in the different tectonic blocks is very heterogeneous, with highly sheared tectonic blocks and almost undeformed ophiolitic lithologies mixed even at outcrop scale (Fig. 7). Conversely, the serpentinitic or metapelitic matrix surrounding the blocks is always strongly sheared. Some of the blocks contain other fabrics and mineral associations that predate their involvement in the mélange, and different blocks reveal different metamorphic conditions. For example, the metasedimentary rocks are always affected by low- to very low- $T$ metamorphism, but the felsic orthogneisses and some amphibolites preserve medium- to high- $T$ mineral assemblages. Most of the blocks of the ophiolitic lithologies contain mineral assemblages of low- to very low- $T$, but some of them exhibit higher-grade mineral assemblages that can include kyanite and garnet.

Ophiolitic lithologies consist of massive metavolcanic rocks, pillow-lava, submarine breccia and pillow-breccia, hyaloclastite, diabase, gabbro and microgabbro, plagiogranite, and highly serpentinized spinel-bearing ultramafic rocks (Arenas and Peinado, 1981; Arenas, 1988; Fig. 7). The serpentinites are the more abundant lithology in the ophiolitic mélange. Figure 8 depicts an idealized reconstruction of ophiolite involved in the Somozas mélange (Arenas, 1988). This column (Fig. 8) contains the first description of one ophiolite involved in the Variscan suture of the northwest Iberian Massif. Variation of the seafloor hydrothermal

\section{SEA-FLOOR HYDROTHERMAL METAMORPHISM}

GREENSCHIST FACIES

\section{AMPHIBOLITE} FACIES

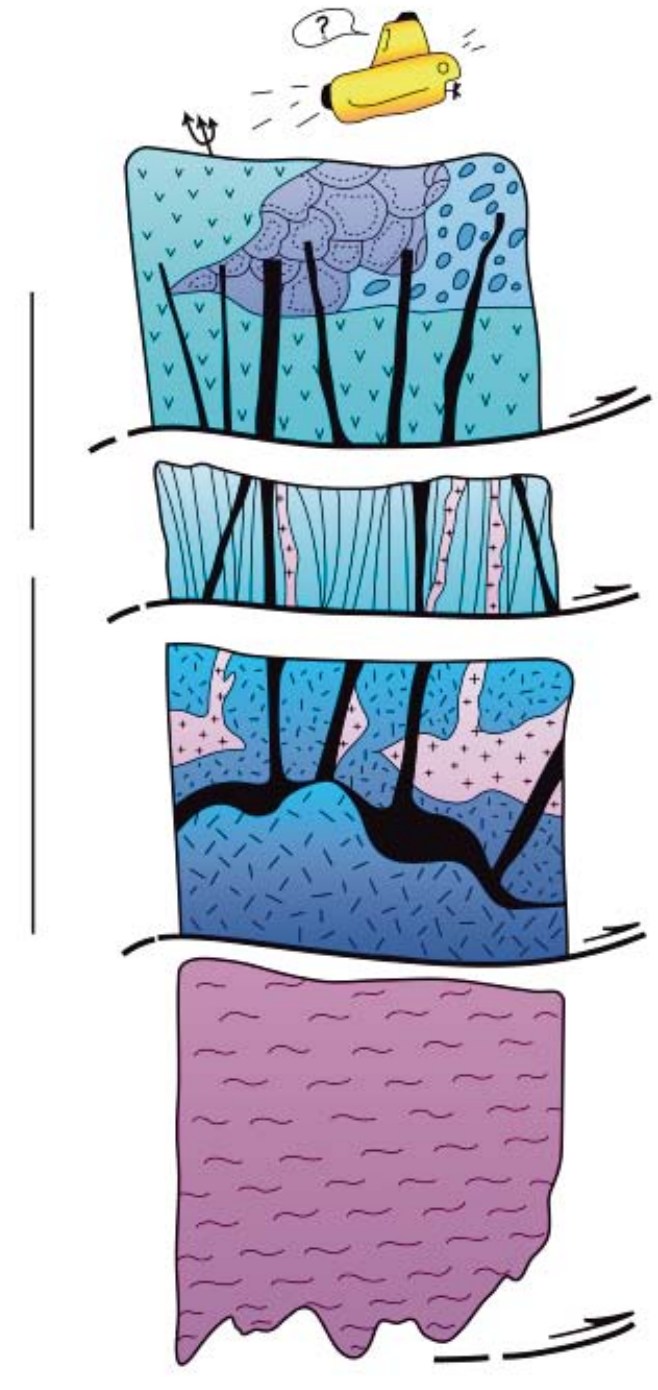

LAVAS, PILLOW-LAVAS, PILLOW-BRECCIAS, HYALOCLASTITE, DIABASE DiKES

DIABASE AND

PLAGIOGRANITE

GABBRO, DIABASE AND PLAGIOGRANITE

ULTRAMAFIC ROCKS (MOSTLY SERPENTINITES)

Figure 8. Idealized reconstruction of the ophiolite that forms part of the Somozas mélange. This ophiolite is currently fragmented and involved in a composite tectonic mélange. 
metamorphism was taken into account in building this ideal section. Metamorphic grade increases from greenschist facies in the upper part of the ophiolite to low- $T$ amphibolite facies in the gabbro layer (hornblende-plagioclase-clinozoisite-quartz-ilmenite). Despite that only hectometer-size original sections of this ophiolite are preserved, it is possible to observe all the different parts of a typical oceanic lithosphere in the field, including large blocks of submarine volcanic rocks with varied lithologies, parts of a sheeted dike complex, and parts of a gabbro-ultramafic complex. According to Arenas (1988), most of the mafic rocks in this ophiolite have characteristic mid-ocean-ridge basalt (MORB) chemical compositions, but volcanic rocks in some tectonic blocks have calc-alkaline basaltic andesite compositions.

So far, no geochronologic data of the lithologies in the Somozas mélange are available, and the age and provenance of the high- $T$ orthogneiss and amphibolite blocks remain unsolved. Some tectonic blocks of marble contain fragments of corals, crinoids, and foraminifers, suggesting an age no older than the Middle Ordovician (Van der Meer Mohr, 1975). Moreover, the rhyolites involved in the lower part of the mélange are almost identical to those of the upper part of the Silurian series that underlies the Somozas mélange. Hence, a Silurian age seems reasonable for the metasedimentary series involved in the mélange.

The Somozas mélange represents tectonic mixing of ophiolite and sediments that probably occurred during the obduction of the ophiolite over the Gondwanan continental margin. The mélange was formed after accretion of both the ophiolites and part of the sediments below the advancing orogenic wedge. The subduction reached only a moderate depth because high- $P$ metamorphism is lacking. This interpretation is consistent with the presence in many tectonic blocks of tectonic fabrics and mineral assemblages that record events earlier than their incorporation in the mélange. Nevertheless, the age and nature of the ocean basin where the ophiolites originated are unknown, and the existence of igneous rocks with different geochemical affinities makes this interpretation even more difficult. In any case, considering the local character of this ophiolitic mélange in the allochthonous complexes of Galicia-Trás-os-Montes (Fig. 1), the possibility that these ophiolites mark the opening of a relatively restricted basin must be considered.

\section{UPPER UNITS}

The upper units consist of a very thick allochthonous lithologic pile (Fig. 1) that records the oldest tectonothermal events and represents the oldest terranes accreted to the eo-Variscan orogenic wedge. The upper and lower ophiolitic units were sequentially accreted below them, followed by the basal units.

Considering the characteristics of their tectonothermal evolution, the upper units are divided in two different assemblages: high- $P$ and high- $T$ upper units (HP-HT upper units) below, and intermediate- $P$ upper units above (Díaz García et al., 1999b; Martínez Catalán et al., 1999; Arenas et al., 2000; Fig. 1). These two lithologic assemblages are always separated from each other by large extensional detachments (Martínez Catalán and Arenas, 1992; Díaz García et al., 1999b; Martínez Catalán et al., 2002; Castiñeiras, 2003). In spite of this tectonic separation, both assemblages are considered parts of the same far-traveled allochthonous terrane (Arenas et al., 1986; Martínez Catalán et al., 1997), based on their lithologic similarity and coeval tectonothermal evolution. During accretion, the lower parts of this terrane reached great depths, developing high- $P$ and high- $T$ metamorphism, whereas the intermediate and upper parts evolved under an intermediate- $P$ gradient.

The more salient feature in the tectonothermal evolution of the upper units is their polymetamorphic nature. Abati et al. (1999) and Fernández-Suárez et al. (2002) have shown that the medium- and high- $T$ units underwent a first metamorphic event at the Cambrian-Ordovician boundary (500-480 Ma; U-Pb on zircon and monazite by TIMS in paragneisses), in addition to a younger, Early Devonian event (400-380 Ma; U-Pb in monazite, titanite, and rutile by TIMS in paragneisses). In this context, an accurate interpretation of the chronology of the high- $P$ and high$T$ event is difficult, and it is only possible by precise analysis of zircons (U-Pb with the secondary ion mass spectrometry (SIMS) method). The most recent data suggest that the Early Devonian event is responsible for the high- $P$ and high- $T$ event (see Fernández-Suárez et al., this volume). Hence, this metamorphism is viewed as early Variscan and related to the early development of the orogenic wedge (Ordóñez Casado et al., 2001). Interpretation of the older Cambrian-Ordovician metamorphic event is much more uncertain, though a relationship with volcanic-arc activity has been suggested (Abati et al., 1999, 2002).

\section{High-Pressure and High-Temperature Upper Units}

The HP-HT upper units consist of a varied lithological succession that includes migmatitic paragneisses, eclogite, high- $P$ mafic granulite, gabbro and coronitic metagabbro, metaperidotite, metapyroxenite, and scarce orthogneisses, as well as their retrogression products, including several types of amphibolite, greenschist, chlorite schist, and serpentinite (Vogel, 1967; Gil Ibarguchi et al., 1990; Arenas, 1991; Mendia, 2000; Arenas and Martínez Catalán, 2002).

Complex internal structure hinders precise reconstruction of the original lithologic succession, but in the Cabo Ortegal Complex, the sequence consists of, from bottom to top, a thick layer of mantle-like ultramafic rocks, mafic rocks of probable gabbroic origin, and a thick pile of sediments intruded by mafic rocks (gabbro and diabase). Considering that the presence of a thick terrigenous sedimentary succession is not characteristic of common oceanic domains, Arenas et al. (1986) suggested that an island-arc environment, either a back arc, a fore-arc or an intraarc, seems to be the more probable dynamic setting for the origin of the upper units. The isotopic ages obtained for the protoliths of some high- $P$ mafic and ultramafic rocks (ca. $500 \mathrm{Ma}$; Ordóñez 
Casado et al., 2001; Santos et al., 2002; Fernández-Suárez et al., this volume) place the age of this arc at the Cambrian-Ordovician boundary.

\section{Intermediate-Pressure Upper Units}

These units consist of a thick pile of terrigenous metasedimentary rocks intruded by large gabbro and granitic bodies, as well as many smaller igneous bodies with variable composition (diorite, tonalite, and some more felsic lithologies). These units crop out widely in the central Órdenes Complex (Fig. 1) and are poorly represented in the Cabo Ortegal Complex (Castiñeiras, 2003). Geochronologic data from the largest igneous bodies (U-Pb on zircon by TIMS; Abati et al., 1999) have yielded 499 $\pm 2 \mathrm{Ma}$ in the Monte Castelo Gabbro, in the western Órdenes
Complex, and $500 \pm 2 \mathrm{Ma}$ in the Corredoiras Orthogneiss, in the eastern part of the same complex. These data are similar to other protolith ages in the HP-HT upper units and confirm the coeval nature of felsic-mafic magmatism in the upper units. Moreover, Fernández-Suárez et al. (2003) obtained a maximum age of sedimentation of ca. $480 \mathrm{Ma}$ for turbidite deposits of the uppermost part of these units (U-Pb laser-ablation inductively coupled plasma-mass spectrometry [ICP-MS] on detrital zircons). It is clear from these data that rock formation in the intermediate- $P$ upper units mostly occurred between the Late Cambrian and the Early Ordovician, although present data cannot exclude the presence of older lithologies in the metasedimentary series surrounding the large igneous massifs.

The uppermost parts of the intermediate- $P$ units in the Órdenes Complex consist of 2000-3000 m of turbidites with a
AVALONIAN PLATE

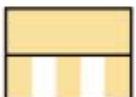

AVALON TERRANE (EMERGED/SUBMERGED)

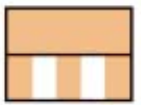

MEGUMA TERRANE (EMERGED /SUBMERGED

POSSIBLE EXTENSION OF MEGUMA TERRANE
VARISCAN BELT

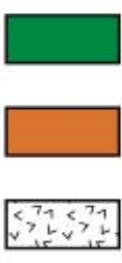

ALLOCHTHONOUS COMPLEXES

PARAUTOCHTHON AND AUTOCHTHON

EXTERNAL THRUST BELT AND FOREDEEP BASINS

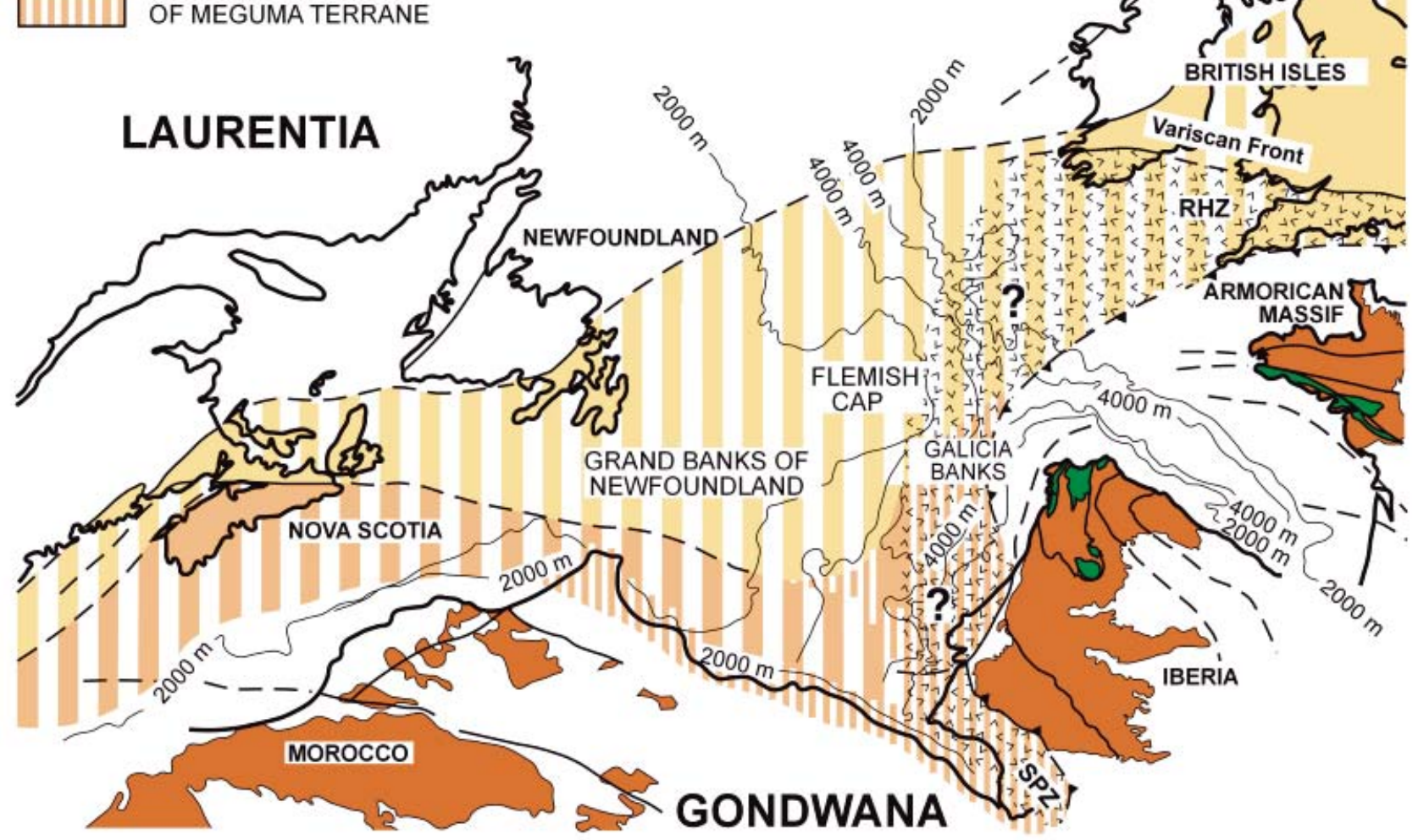

Figure 9. Reconstruction of Pangea in the vicinity of Iberia (based on Lefort, 1989; Skehan and Rast, 1995; Martínez Catalán et al., 1997). The figure shows the present position of the Avalon terrane and the allochthonous complexes of northwest Iberia. RHZ-Rhenohercynian zone; SPZ_-South Portuguese zone. 
probable Ordovician age (Fernández-Suárez et al., 2003). The lithologies are flysch-like and consist of alternating graywackes and pelites, with scarce conglomerate. Coarse-grained graywacke and conglomerate contain abundant igneous rock, slate, chert, and bipyramidal quartz fragments. The abundance of igneous rock fragments and the immature character of the graywackes, together with the geochemical characteristics of some metaigneous rocks of other intermediate- $P$ upper units (Andonaegui et al., 2002; Castiñeiras, 2003), suggest an island-arc setting for the assemblage. The lack of volcanic successions indicates that the upper parts of the arc edifice have not been preserved, whereas the turbidites probably represent the filling of a forearc or backarc basin. Such an island arc would have been generated in the peri-Gondwanan realm, according to the age populations yielded by the detrital zircons from the turbidites (Fernández-Suárez et al., 2003).

Considering the tectonothermal evolution of the intermediate- $P$ upper units, their lowest parts exhibit metamorphic conditions of intermediate- $P$ granulite facies (Abati, 2002; Abati et al., 2003), while the middle parts were recrystallized in the amphibolite facies, and the uppermost parts only reached the greenschist facies. According to their structural and metamorphic characteristics, the upper intermediate- $P$ and HP-HT units define a section of an orogenic wedge with up to $10 \mathrm{~km}$ of present thickness, where the metamorphic grade increases gradually from top to bottom. However, the currently observed section is only a remnant of a thick pile, which, according to the $P$ - $T$ conditions deduced for the HP-HT mineral assemblages, attained a thickness of 70-80 km.

\section{TERRANES AND ACCRETIONARY HISTORY}

The allochthonous complexes of the Galicia-Trás-os-Montes zone can be grouped in several terranes, some of which underwent very large displacements before accretion to the Variscan orogenic wedge and so are considered far-traveled terranes. The origin and meaning of these terranes as well as their evolution during the Paleozoic have been the object of recent contributions (Martínez Catalán et al., 1997; Díaz García et al., 1999a; Martínez Catalán et al., 1999; Andonaegui et al., 2002; Castiñeiras, 2003; Sánchez Martínez, 2003), which have improved the understanding of the Paleozoic evolution of the peri-Gondwanan realm where the Iberian Massif is located (Figs. 9 and 10).

As described in the previous section, the upper units of the allochthonous complexes (both HP-HT and intermediate- $P$ upper units) seem to form part of a single allochthonous terrane, accreted to Laurussia during an eo-Variscan event (ca. 420-400 Ma; Fig. 10C), the lower parts of which were affected by high- $P$ and high- $T$ metamorphism. The accretion to Laurussia occurred after the complete closure of an intervening ocean, which could have been the Iapetus (Scotese, 2001; Stampfli and Borel, 2002) or the Tornquist Ocean, depending on the unconstrained paleoposition of Iberia at that time. The ophiolites related to that suture could have overlain the upper units of the allochthonous com- plexes (Fig. 10C) but are not represented in the northwest Iberian Massif. They could be presently located in the submerged continental margin of Galicia, in the Grand Banks of Newfoundland, and/or in the poorly exposed and poorly known Tornquist suture, depending on the correlation between the upper units of the Galicia-Trás-os-Montes zone and the allochthonous terranes of North America and Central Europe (Figs. 9 and 10). It seems that the first eo-Variscan tectonothermal event recorded in the upper units of Galicia occurred ca. 420-430 Ma, and hence, it is somewhat younger than the estimated time of accretion of Avalon to Laurussia, dated at 460-430 Ma (Cawood et al., 1995; Murphy et al., 1995).

The geochemical characteristics of the metaigneous rocks in the upper units suggest generation in an island-arc setting (Andonaegui et al., 2002; Santos et al., 2002; Castiñeiras, 2003). The immature and turbiditic character of the low- $T$ metasediments that occupy the uppermost parts of these units also favors an island-arc setting. Hence, the upper units probably represent different parts of an island arc that evolved near the CambrianOrdovician boundary in a peri-Gondwanan realm (Abati et al., 1999; Santos et al., 2002; Fernández-Suárez et al., 2003). The high- $T$ metamorphic event that affected the upper units at 500 480 Ma (Abati et al., 1999; Fernández-Suárez et al., 2002) was probably related to the evolution of this arc.

The more problematic aspects of the evolution of this island arc are its precise location in the peri-Gondwanan realm and whether or not it formed part of the Avalon microcontinent. Taking into account the different terranes preserved in northwest Iberia, this island arc was separated from Gondwana by an oceanic domain represented by the lower ophiolitic units. The name Galician ocean is used in this contribution, but it can equally be considered as a part of the large Rheic Ocean, which probably developed behind an island arc (see the paleomap of Scotese [2001] for the Avalonian domain at $480 \mathrm{Ma}$ ).

In Galicia, the metabasic rocks of the lower ophiolites have compositions suggesting an origin in a marginal basin (Sánchez Martínez et al., this volume), and some of the ophiolites include thick metasedimentary formations alternating with the mafic rocks. These facts suggest that most of the mafic rocks in these ophiolites were derived from volcanic rocks. In this context, the island arc represented by the upper units might have originated as a volcanic arc associated with the northern continental margin of Gondwana (Fig. 10A). The drift of the arc from the continental margin caused the opening of a marginal basin (Fig. 10B), which, according to the available continental reconstructions for the Cambrian-Ordovician boundary, should have been connected with the early opening of the Rheic Ocean. The age populations of detrital zircons from turbidites support this interpretation (FernándezSuárez et al., 2003). This model is similar to that proposed for the rapid opening of the Sea of Japan in middle Miocene time, which caused a very rapid drift of a volcanic arc from the continental margin of Eurasia toward the Pacific Ocean. In the present island arc, represented by the Japanese Islands, only the metamorphic 


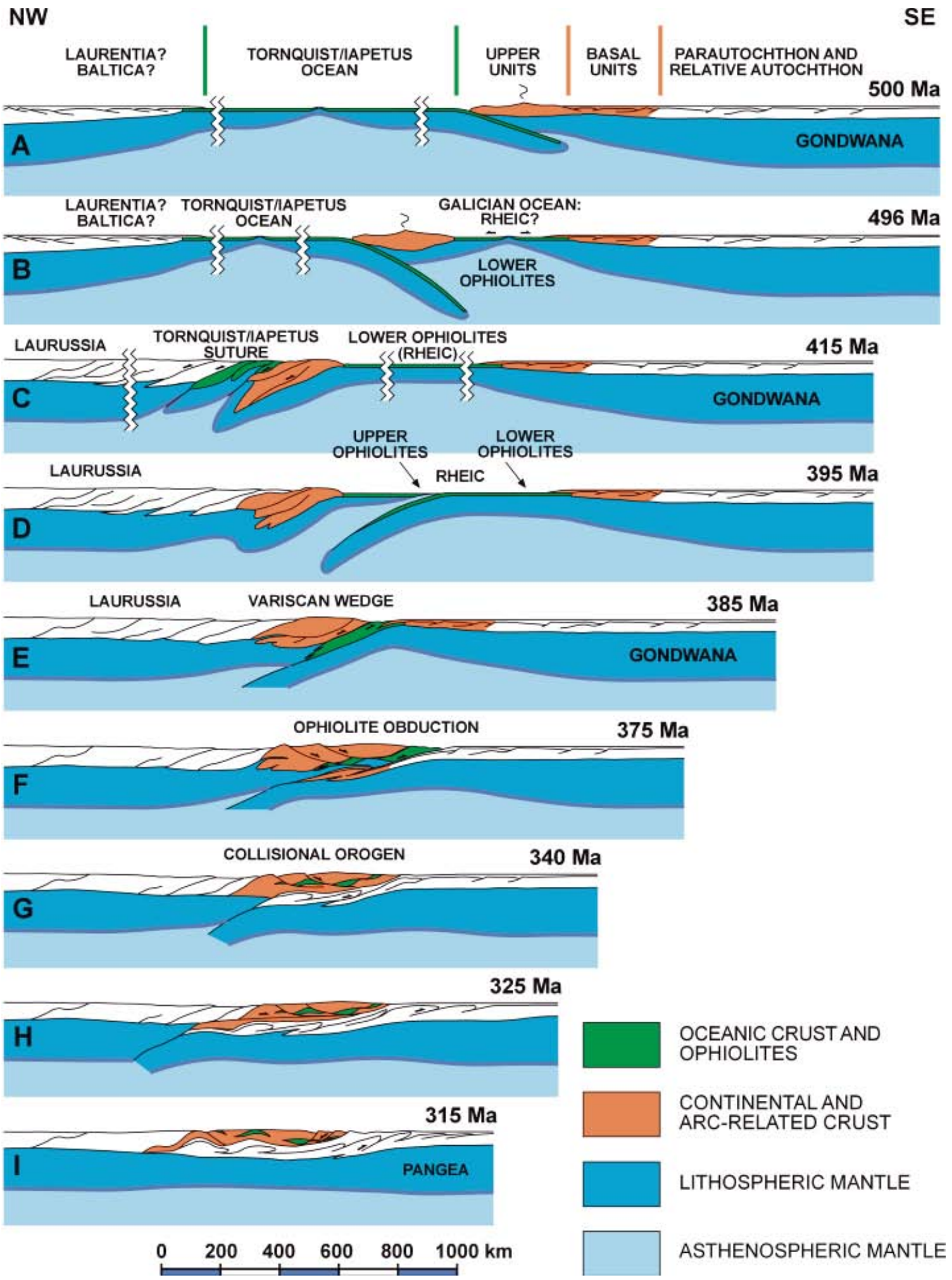

Figure 10. Proposed Paleozoic evolution of the terranes included in the allochthonous complexes of northwestern Iberian Massif. The reconstruction shows the tectonic setting of terrane generation in the peri-Gondwanan realm during Cambrian and Ordovician times, the accretion of these terranes to Laurussia, and the final collision between Laurussia and Gondwana. Plate configuration during Cambrian and Ordovician times is largely based in Scotese (2001). The name Galician ocean defines the oceanic domain originated by the opening of a marginal basin in the periGondwanan realm. This Galician ocean could represent either a part of the larger Rheic Ocean, or the first stages of the opening of this ocean in its eastern branch (see Scotese, 2001). 
belt located to the west, the Hida belt, preserves remnants of the Eurasian basement (Dallmeyer and Takasu, 1992).

Closing of the Galician ocean probably began in Late Silurian-Early Devonian times and seems to have occurred through intraoceanic subduction (Fig. 10D). The upper ophiolitic units, which are dated at ca. $395 \mathrm{Ma}$ (Díaz García et al. 1999a) and that reveal chemical compositions characteristic of suprasubduction zone ophiolites (Pin et al., 2002; Sánchez Martínez et al., this volume), were formed at this time (Fig. 10D). These suprasubduction zone ophiolites were soon subducted and accreted below the upper units (ca. 391-376 Ma). Later on, the accreted remnants of these ophiolites, together with some remnants of the early opening of the Galician ocean, located closer to the Gondwanan continental margin, were accreted to the orogenic wedge and preserved as the lower ophiolitic units (Fig. 10E).

There is general agreement on the interpretation of the basal units as the outer edge of the Gondwanan continental margin (Arenas et al., 1986; Martínez Catalán et al., 1996). This relatively thin continental crust was subducted during the first stages of the collision, when the Variscan deformation reached Gondwana (ca. 380-370 Ma; Rodríguez et al., 2003; Fig. 10F). This margin was the site of voluminous but poorly studied 460-480 Ma magmatism during the Early to Middle Ordovician. The meaning of this magmatism is unclear, although it is generally assigned to rifting on the Gondwanan margin. However, this crustal extension is somewhat younger than the drifting away of the upper units from Gondwana, and it could reflect the local opening of a small ocean basin separating the basal units from mainland Gondwana. The Somozas mélange, structurally below the basal units of the Cabo Ortegal Complex that include an ophiolitic association, makes this hypothesis feasible, although confirmation will have to wait until new isotopic ages and a detailed geochemical data are available.

No ophiolites underlie the schistose domain, which is in thrust contact above the metasedimentary series of the Central Iberian zone. So, no suture is present between the autochthon and parautochthon, and no significant differences in the metamorphic evolution have been found between both assemblages. Consequently, the parautochthon cannot be considered an exotic terrane. Rather, it may be a tectonic unit that belonged to the Gondwanan continental margin and was incorporated below the allochthonous complexes during emplacement.

\section{ACKNOWLEDGMENTS}

The authors thank Harry Y. McSween for revision of the first version of the manuscript. Important editorial help and enriching correction by Robert Hatcher Jr. is kindly acknowledged. This research was funded by the Spanish Dirección General de Investigación (Ministerio de Ciencia y Tecnología and Ministerio de Educación y Ciencia) and includes results from projects BTE2001-0963-CO2 and CGL2004-04306-CO2/BTE.

\section{REFERENCES CITED}

Ábalos, B., Azcárraga, J., Gil Ibarguchi, J.I., Mendia, M., and Puelles, P., 2000, Mapa Geológico del Complejo de Cabo Ortegal (NO de España): Instituto Universitario de Xeoloxía Isidro Parga Pondal, Universidade da Coruña, Coruña, Spain, Servicio de Publicacións, 60 p.

Abati, J., 2002, Petrología metamórfica y geocronología de la unidad culminante del Complejo de Órdenes en la región de Carballo (Galicia, NW del Macizo Ibérico): Nova Terra, v. 20, 269 p.

Abati, J., Dunning, G.R., Arenas, R., Díaz García, F., González Cuadra, P., Martínez Catalán, J.R., and Andonaegui, P., 1999, Early Ordovician orogenic event in Galicia (NW Spain): Evidence from U-Pb ages in the uppermost unit of the Órdenes Complex: Earth and Planetary Science Letters, v. 165, p. 213-228, doi: 10.1016/S0012-821X(98)00268-4.

Abati, J., Arenas, R., Martínez Catalán, J.R., and Díaz García, F., 2003, Anticlockwise $P-T$ path of granulites from the Monte Castelo Gabbro (Órdenes Complex, NW Spain): Journal of Petrology, v. 44, p. 305-327, doi: 10.1093/petrology/44.2.305.

Alcock, J., Arenas, R., and Martínez Catalán, J.R., 2005, Shear stress in subducting continental margin from high-pressure, moderate-temperature metamorphism in the Órdenes Complex, Galicia: NW Spain: Tectonophysics, v. 397, p. 181-194, doi: 10.1016/j.tecto.2004.11.009.

Andonaegui, P., González del Tánago, J., Arenas, R., Abati, J., Martínez Catalán, J.R., Peinado, M., and Díaz García, F., 2002, Tectonic setting of the Monte Castelo Gabbro (Órdenes Complex, NW Iberian Massif): Evidence for an arc-related terrane in the hanging wall to the Variscan suture, in Martínez Catalán, J.R., Hatcher, R.D., Jr., Arenas, R., and Díaz García, F., eds., Variscan-Appalachian Dynamics: The Building of the Late Paleozoic Basement: Geological Society of America Special Paper 364, p. $37-56$.

Arenas, R., 1988, Evolución petrológica y geoquímica de la unidad alóctona inferior del complejo metamórfico básico-ultrabásico de Cabo Ortegal (Unidad de Moeche) y del Silúrico parautóctono, Cadena Hercínica Ibérica (NW de España): Corpus Geologicum Gallaecia, v. IV, 543 p.

Arenas, R., 1991, Opposite P,T,t paths of Hercynian metamorphism between the upper units of the Cabo Ortegal Complex and their substratum (northwest of the Iberian Massif): Tectonophysics, v. 191, p. 347-364, doi: 10.1016/0040-1951(91)90067-3.

Arenas, R., and Martínez Catalán, J.R., 2002, Prograde development of corona textures in metagabbros of the Sobrado unit (Órdenes Complex, northwestern Iberian Massif), in Martínez Catalán, J.R., Hatcher, R.D., Jr., Arenas, R., and Díaz García, F., eds., Variscan-Appalachian Dynamics: The Building of the Late Paleozoic Basement: Geological Society of America Special Paper 364, p. 73-88.

Arenas, R., and Peinado, M., 1981, Presencia de pillow-lavas en las metavolcanitas submarinas de las proximidades de Espasante, Cabo Ortegal, NW de España: Cuadernos de Geología Ibérica, v. 7, p. 105-119.

Arenas, R., Gil Ibarguchi, J.I., González Lodeiro, F., Klein, E., Martínez Catalán, J.R., Ortega Gironés, E., Pablo Maciá, J.G., and Peinado, M., 1986, Tectonostratigraphic units in the complexes with mafic and related rocks of the NW of the Iberian Massif: Hercynica, v. II, p. 87-110.

Arenas, R., Farias, P., Gallastegui, G., Gil Ibarguchi, J.I., González Lodeiro, F., Klein, E., Marquínez, J., Martín Parra, L.M., Martínez Catalán, J.R., Ortega, E., de Pablo Maciá, J.G., Peinado, M., and Rodríguez Fernández, L.R., 1988, Características geológicas y significado de los dominios que componen la Zona de Galicia-Trás-os-Montes: Actas del II Congreso Geológico de España, Simposios, p. 75-84.

Arenas, R., Rubio Pascual, F.J., Díaz García, F., and Martínez Catalán, J.R., 1995, High-pressure micro-inclusions and development of an inverted metamorphic gradient in the Santiago schists (Ordenes Complex, NW Iberian Massif, Spain): Evidence of subduction and syncollisional decompression: Journal of Metamorphic Geology, v. 13, p. 141-164.

Arenas, R., Abati, J., Martínez Catalán, J.R., Díaz García, F., and Rubio Pascual, F.J., 1997, P-T evolution of eclogites from the Agualada unit (Órdenes Complex, NW Iberian Massif, Spain): Implications for crustal subduction: Lithos, v. 40, p. 221-242, doi: 10.1016/S0024-4937(97)00029-7.

Arenas, R., Díaz García, F., Martínez Catalán, J.R., Abati, J., González Cuadra, 
P., Andonaegui, P., González del Tánago, J., Rubio Pascual, F., Castiñeiras, P., and Gómez Barreiro, J., 2000, Structure and evolution of the Ordenes Complex: A Coruña, Spain, Basement Tectonics 15, Pre-Conference Field Trip, 160 p.

Arenas, R., Martínez Catalán, J.R., Sánchez Martínez, S., Fernández-Suárez, J., Andonaegui, P., Pearce, J.A., and Corfu, F., 2005, The Vila de Cruces Ophiolite: A remnant of the early Rheic Ocean in the Variscan suture of Galicia (NW Iberian Massif) [abs.], in IGCP 497: The Rheic Ocean-Its Origin Evolution and Correlatives: Portsmouth, University of Portsmouth, p. 19-20.

Arps, C.E.S., 1970, Petrology of a part of the western Galicia basement between the Río Jallas and the Ría de Arosa (NW Spain) with emphasis on zircon investigations: Leidse Geologische Mededelingen, v. 46, p. 57-155.

Azcárraga, J., 2000, Evolución tectónica y metamórfica de los mantos inferiores de grado alto y alta presión del complejo de Cabo Ortegal: Nova Terra, v. 17, $346 \mathrm{p}$.

Castiñeiras, P., 2003, Origen y evolución tectonotermal de las unidades de O Pino y Cariño (Complejos Alóctonos de Galicia) [Ph.D. thesis]: Madrid, Spain, Universidad Complutense, $281 \mathrm{p}$.

Cawood, P.A., Van Gool, J.A.M., and Dunning, G.R., 1995, Collisional tectonics along the Laurentian margin of the Newfoundland Appalachians, in Hibbard, J.P., van Staal, C.R., and Cawood, P.A., eds., Current Perspectives in the Appalachian-Caledonian Orogen: Geological Association of Canada Special Paper 41, p. 283-301.

Dallmeyer, R.D., and Gil Ibarguchi, J.I., 1990, Age of amphibolitic metamorphism in the ophiolitic unit of the Morais allochthon (Portugal): Implications for early Hercynian orogenesis in the Iberian Massif: Geological Society [London] Journal, v. 147, p. 873-878.

Dallmeyer, R.D., and Takasu, A., 1992, Plate tectonic setting of the Japanese Islands, in Dallmeyer, R.D., ed., Terrane Accretion in Southwest Japan: Shimane, Japan, A Geotraverse Excursion, Chapter I, p. 3-5.

Dallmeyer, R.D., Ribeiro, A., and Marques, F., 1991, Polyphase Variscan emplacement of exotic terranes (Morais and Bragança Massifs) onto Iberian successions: Evidence from ${ }^{40} \mathrm{Ar} /{ }^{39} \mathrm{Ar}$ mineral ages: Lithos, v. 27, p. 133-144, doi: 10.1016/0024-4937(91)90025-G.

Dallmeyer, R.D., Martínez Catalán, J.R., Arenas, R., Gil Ibarguchi, J.I., Gutiérrez-Alonso, G., Farias, P., Aller, J., and Bastida, F., 1997, Diachronous Variscan tectonothermal activity in the NW Iberian Massif: Evidence from ${ }^{40} \mathrm{Ar} /{ }^{39} \mathrm{Ar}$ dating of regional fabrics: Tectonophysics, v. 277 , p. $307-$ 337, doi: 10.1016/S0040-1951(97)00035-8.

Díaz García, F., 1990, La geología del sector occidental del Complejo de Órdenes (Cordillera Hercínica, NW de España): Nova Terra, v. 3, 269 p.

Díaz García, F., Arenas, R., Martínez Catalán, J.R., González del Tánago, J., and Dunning, G.R., 1999a, Tectonic evolution of the Careón Ophiolite (northwest Spain): A remnant of oceanic lithosphere in the Variscan belt: The Journal of Geology, v. 107, p. 587-605, doi: 10.1086/314368.

Díaz García, F., Martínez Catalán, J.R., Arenas, R., and González Cuadra, P., 1999b, Structural and kinematic analysis of the Corredoiras detachment: Evidence for early Variscan synconvergent extension in the Ordenes Complex, NW Spain: International Journal of Earth Sciences, v. 88, p. 337-351, doi: 10.1007/s005310050269.

Farias, P., Gallastegui, G., González Lodeiro, F., Marquínez, J., Martín-Parra, L.M., Martínez Catalán, J.R., de Pablo Maciá, J.G., and Rodríguez Fernández, L.R., 1987, Aportaciones al conocimiento de la litoestratigrafía y estructura de Galicia Central: Memorias Museo e Laboratorio Mineralógico e Geológico, Faculdade de Ciências, Universidade de Porto, v. 1, p. 411-431.

Fernández-Suárez, J., Corfu, F., Arenas, R., Marcos, A., Martínez Catalán, J.R., Díaz García, F., Abati, J., and Fernández, F.J., 2002, U-Pb evidence for a polyorogenic evolution of the HP-HT units of the NW Iberian Massif: Contributions to Mineralogy and Petrology, v. 143, p. 236-253, doi: 10.1007/s00410-001-0337-2.

Fernández-Suárez, J., Díaz García, F., Jeffries, T.E., Arenas, R., and Abati, J., 2003, Constraints on the provenance of the uppermost allochthonous terrane of the NW Iberian Massif: Inferences from detrital zircon $\mathrm{U}-\mathrm{Pb}$ ages: Terra Nova, v. 15, p. 138-144, doi: 10.1046/j.1365-3121.2003.00479.x.

Fernández-Suárez, J., Arenas, R., Abati, J., Martínez Catalán, J.R., Whitehouse, M.J., and Jeffries, T.E., 2007, this volume, U-Pb chronometry of polymetamorphic high-pressure, in Hatcher, R.D., Jr., Carlson, M.P., McBride, J.H., and Martínez Catalán, J.R., eds., 4-D Framework of Continental Crust: Geological Society of America Memoir 200, doi: 10.1130/2007.1200(24)

Floor, P., 1966, Petrology of an aegirine-ribeckite gneiss-bearing part of the
Hesperian Massif: The Galiñeiro and surrounding areas, Vigo, Spain: Leidse Geologische Mededelingen, v. 36, p. 1-204.

Fombella Blanco, M., 1984, Age palynologique du Blastomilonitic Graben, Zone Occidentale de la Galice: Revue de Micropaleontologie, v. 27, p. 113-117.

García Garzón, J., de Pablo Maciá, J.G., and Llamas Borrajo, J.F., 1981, Edades absolutas obtenidas mediante el método Rb-Sr de dos cuerpos de ortogneises en Galicia Occidental: Boletín Geológico y Minero, v. 92, p. 443-455.

Gil Ibarguchi, J.I., 1995, Petrology of jadeite-metagranite and associated orthogneiss from the Malpica-Tui allochthon (northwest Spain): European Journal of Mineralogy, v. 7, p. 403-415.

Gil Ibarguchi, J.I., and Ortega Gironés, E., 1985, Petrology, structure and geotectonic implications of glaucophane-bearing eclogites and related rocks from the Malpica-Tui (MT) unit, Galicia, northwest Spain: Chemical Geology, v. 50, p. 145-162, doi: 10.1016/0009-2541(85)90117-2.

Gil Ibarguchi, J.I., Mendia, M., Girardeau, J., and Peucat, J.J., 1990, Petrology of eclogites and clinopyroxene-garnet metabasites from the Cabo Ortegal Complex (northwestern Spain): Lithos, v. 25, p. 133-162, doi: 10.1016/0024-4937(90)90011-O.

Gil Ibarguchi, J.I., Ábalos, B., Azcárraga, J., Mendia, M., and Puelles, P., 2000 A petrological and structural excursion through the high-grade/high-pressure allochthonous units of the Cabo Ortegal complex (NW Spain): A Coruña, Spain, Basement Tectonics 15, Mid-Conference Field Trip, 59 p.

Lefort, J.P., 1989, Basement Correlation across the North Atlantic: Berlin, Springer, $148 \mathrm{p}$.

Llana-Fúnez, S., 2001, La estructura de la Unidad de Malpica-Tui (Cordillera Varisca en Iberia): Madrid, Instituto Geológico y Minero de España, Serie Tesis Doctorales, v. 1, 295 p.

Llana-Fúnez, S., and Marcos, A., 2002, Structural record during exhumation and emplacement of high-pressure-low-to intermediate-temperature rocks in the Malpica-Tui unit (Variscan belt of Iberia), in Martínez Catalán, J.R., Hatcher, R.D., Jr., Arenas, R., and Díaz García, F., eds., Variscan-Appalachian Dynamics: The Building of the Late Paleozoic Basement: Geological Society of America Special Paper 364, p. 125-142.

Marcos, A., Fernández Rodríguez, J.J., and Llana-Fúnez, S., 2000, Structure of the Cabo Ortegal Nappe: A Coruña, Spain, Basement Tectonics 15, MidConference Field Trip, $15 \mathrm{p}$

Marcos, A., Farias, P., Galán, G., Fernández, J.J., and Llana-Fúnez, S., 2002 Tectonic framework of the Cabo Ortegal Complex: A slab of lower crust exhumed in the Variscan orogen (northwestern Iberia Peninsula), in Martínez Catalán, J.R., Hatcher, R.D., Jr., Arenas, R., and Díaz García, F., eds., Variscan-Appalachian Dynamics: The Building of the Late Paleozoic Basement: Geological Society of America Special Paper 364, p. 143-162.

Martínez Catalán, J.R., and Arenas, R., 1992, Deformación extensional de las unidades alóctonas superiores de la parte oriental del Complejo de Órdenes (Galicia): Geogaceta, v. 11, p. 108-111.

Martínez Catalán, J.R., Arenas, R., Díaz García, F., Rubio Pascual, F.J., Abati, J., and Marquínez, J., 1996, Variscan exhumation of a subducted Paleozoic continental margin: The basal units of the Órdenes Complex, Galicia: NW Spain: Tectonics, v. 15, p. 106-121, doi: 10.1029/95TC02617.

Martínez Catalán, J.R., Arenas, R., Díaz García, F., and Abati, J., 1997, Variscan accretionary complex of northwest Iberia: Terrane correlation and succession of tectonothermal events: Geology, v. 25, p. 1103-1106, doi: 10.1130/0091-7613(1997)025<1103:VACONI >2.3.CO;2

Martínez Catalán, J.R., Arenas, R., Díaz García, F., and Abati, J., 1999, Allochthonous units in the Variscan belt of NW Iberia: Terranes and accretionary history, in Sinha, A.K., ed., Basement Tectonics, Volume 13: Amsterdam, Kluwer Academic Publishers, p. 65-84.

Martínez Catalán, J.R., Díaz García, F., Arenas, R., Abati, J., Castiñeiras, P., González Cuadra, P., Gómez Barreiro, J., and Rubio Pascual, F.J., 2002, Thrusts and detachment systems in the Órdenes Complex (northwestern Spain): Implications for the Variscan-Appalachian geodynamics, in Martínez Catalán, J.R., Hatcher, R.D., Jr., Arenas, R., and Díaz García, F., eds., Variscan-Appalachian Dynamics: The Building of the Late Paleozoic Basement: Geological Society of America Special Paper 364, p. 163-182.

Martínez Catalán, J.R., Arenas, R., Díaz García, F., Gómez-Barreiro, J., González Cuadra, P., Abati, J., Castiñeiras, P., Fernández-Suárez, J., Sánchez Martínez, S., Andonaegui, P., González Clavijo, E., Díez Montes, A., Rubio Pascual, F.J., and Valle Aguado, B., 2007, Space and time in the tectonic evolution of the northwestern Iberian Massif: Implications for the comprehension of the Variscan belt, in Hatcher, R.D., Jr., Carlson, M.P., McBride, J.H., and Martínez Catalán, J.R., eds., 4-D Framework of Continental Crust: Geological Society of America Memoir 200, doi: 
$10.1130 / 2007.1200(21)$.

Matte, Ph., 1995, Southern Uralides and Variscides: Comparison of their anatomies and evolutions: Geologie en Mijnbouw, v. 74, p. 151-166.

Matte, Ph., 2001, The Variscan collage and orogeny (480-290 Ma) and the tectonic definition of the Armorica microplate: A review: Terra Nova, v. 13, p. 122-128, doi: 10.1046/j.1365-3121.2001.00327.x.

Mendia, M., 2000, Petrología de la unidad eclogítica del Complejo de Cabo Ortegal (NW de España): Nova Terra, v. 16, 424 p.

Montero, P., 1993, Geoquímica y petrogénesis del Complejo Peralcalino de la Sierra del Galiñeiro (Pontevedra, España) [Ph.D. thesis]: Oviedo, Spain, Universidad de Oviedo, 318 p.

Murphy, J.B., Nance, R.D., Keppie, J.D., Dostal, J., and Coursens, B.L., 1995, Odyssey of West Avalonia: Isotopic constraints for Late Proterozoic. III: Early Silurian paleogeography, in Hibbard, J.P., van Staal, C.R., and Cawood, P.A., eds., Current Perspectives in the Appalachian-Caledonian Orogen: Geological Association of Canada Special Paper 41, p. 227-237.

Ordóñez Casado, B., Gebauer, D., Schäfer, H.J., Gil Ibarguchi, J.I., and Peucat, J.J., 2001, A single Devonian subduction event for the HP/HT metamorphism of the Cabo Ortegal Complex within the Iberian Massif: Tectonophysics, v. 332, p. 359-385, doi: 10.1016/S0040-1951(00)00210-9.

Pereira, E., Ribeiro, A., de Carvalho, G., Noronha, F., Ferreira, N., and Monteiro, J.M., 1989, Carta Geológica de Portugal, Folha 1: Lisboa, Serviços Geológicos de Portugal, escala 1:200,000.

Pereira, E., Ribeiro, A., Marques, F., Munhá, J., Meireles, C., Ribeiro, M.A., Pereira, D, Noronha, F., and Ferreira, N., 2000, Carta Geológica de Portugal, Folha 2: Lisboa, Serviços Geológicos de Portugal, escala 1:200,000.

Peucat, J.J., Bernard-Griffiths, J., Gil Ibarguchi, J.I., Dallmeyer, R.D., Menot, R.P., Cornichet, J., and Iglesias Ponce de León, M., 1990, Geochemical and geochronological cross section of the deep Variscan crust: The Cabo Ortegal high-pressure nappe (northwestern Spain): Tectonophysics, v. 177, p. 263-292, doi: 10.1016/0040-1951(90)90285-G.

Pin, C., Ortega Cuesta, L.A., and Gil Ibarguchi, J.I., 1992, Mantle-derived, early Paleozoic A-type metagranitoids from the NW Iberian Massif: Nd isotope and trace-element constraints: Bulletin de la Société Géologique de France, v. 163, p. 483-494.

Pin, C., Paquette, J.L., Santos Zalduegui, J.F., and Gil Ibarguchi, J.I., 2002 Early Devonian suprasubduction-zone ophiolite related to incipient collisional processes in the western Variscan belt: The Sierra de Careón unit, Órdenes Complex, Galicia, in Martínez Catalán, J.R., Hatcher, R.D., Jr., Arenas, R., and Díaz García, F., eds., Variscan-Appalachian Dynamics: The Building of the Late Paleozoic Basement: Geological Society of America Special Paper 364, p. 57-71.

Platt, J.P., 1986, Dynamics of orogenic wedges and the uplift of highpressure metamorphic rocks: Geological Society of America Bulletin, v. 97, p. 1037-1053, doi: 10.1130/0016-7606(1986)97<1037: DOOWAT $>2.0 . \mathrm{CO} ; 2$.

Priem, H.N.A., Boelrijk, N.A.I.M., Verschure, R.H., Hebeda, E.H., and Floor, P., 1966, Isotopic evidence for Upper-Cambrian or Lower-Ordovician granite emplacement in the Vigo area, north-western Spain: Geologie en Mijnbouw, v. 45, p. 36-40.

Puelles, P., 2003, Deformación, metamorfismo y exhumación de las granulitas de alta presión de La Bacariza (Complejo de Cabo Ortegal, NO España), [Ph.D. thesis]: Leioa, Spain, Universidad del País Vasco, 372 p.

Ribeiro, A., 1974, Contribution a l'Etude Tectonique de Trás-os-Montes Oriental: Memorias dos Serviços Geológicos de Portugal 24, 179 p.

Ribeiro, A., Pereira, E., and Dias, R., 1990, Central-Iberian zone: Allochthonous sequences. Structure in the northwest of the Iberian Peninsula, in Dallmeyer, R.D., and Martínez García, E., eds., Pre-Mesozoic Geology of Iberia: Berlin, Springer-Verlag, p. 220-236.

Ries, A.C., and Shackleton, R.M., 1971, Catazonal complexes of north-west
Spain and north Portugal, remnants of a Hercynian thrust plate: Nature Physical Sciences, v. 234, p. 65-68.

Rodríguez, J., 2003, Recristalización y deformación de litologías supracorticales sometidas a metamorfismo de alta presión (complejo de Malpica-Tuy, NO del Macizo Ibérico) [Ph.D. thesis]: Leioa, Spain, Universidad del País Vasco, $410 \mathrm{p}$.

Rodríguez, J., Cosca, M.A., Gil Ibarguchi, J.I., and Dallmeyer, R.D., 2003, Strain partitioning and preservation of ${ }^{40} \mathrm{Ar} /{ }^{39} \mathrm{Ar}$ ages during Variscan exhumation of a subducted crust (Malpica-Tui complex, NW Spain): Lithos, v. 70, p. 111-139, doi: 10.1016/S0024-4937(03)00095-1.

Rubio Pascual, F.J., Arenas, R., Díaz García, F., Martínez Catalán, J.R., and Abati, J., 2002, Contrasting high-pressure metabasites from the Santiago unit (Órdenes Complex, northwestern Iberian Massif, Spain), in Martínez Catalán, J.R., Hatcher, R.D., Jr., Arenas, R., and Díaz García, F., eds., Variscan-Appalachian Dynamics: The Building of the Late Paleozoic Basement: Geological Society of America Special Paper 364, p. 105-124. Sánchez Martínez, S., 2003, Geoquímica de las unidades ofiolíticas de Purrido y Moeche (Complejo de Cabo Ortegal, NW del Macizo Ibérico) [D.E.A.] Madrid, Spain, Universidad Complutense, 206 p

Sánchez Martínez, S., Arenas, R., Andonaegui, P., Martínez Catalán, J.R., and Pearce, J.A., 2007, Geochemistry of two associated ophiolites from the Cabo Ortegal Complex (Variscan belt of NW Spain), in Hatcher, R.D., Jr., Carlson, M.P., McBride, J.H., and Martínez Catalán, J.R., eds., 4-D Framework of Continental Crust: Geological Society of America Memoir 200, doi: 10.1130/2007.1200(23).

Santos, J.F., Schärer, U., Gil Ibarguchi, J.I., and Girardeau, J., 2002, Genesis of pyroxenite-rich peridotite at Cabo Ortegal (NW Spain): Geochemical and Pb-Sr-Nd isotope data: Journal of Petrology, v. 43, p. 17-43, doi: 10.1093/petrology/43.1.17.

Santos Zalduegui, J.F., 1995, Geocronología y geoquímica isotópica de diferentes unidades de los complejos alóctonos de Cabo Ortegal y Malpica-Tuy (NO de España): Nova Terra, v. 11, 178 p

Scotese, C.R., 2001, Atlas of Earth History: Arlington, Texas, PALEOMAP Project, $52 \mathrm{p}$.

Skehan, J.V., and Rast, N., 1995, Late Proterozoic to Cambrian evolution of the Boston Avalon terrane, in Hibbard, J.P., van Staal, C.R., and Cawood, P.A., eds., Current Perspectives in the Appalachian-Caledonian Orogen: Geological Association of Canada Special Paper 41, p. 207-225.

Stampfli, G.M., and Borel, G.D., 2002, A plate tectonic model for the Paleozoic and Mesozoic constrained by dynamic plate boundaries and restored synthetic oceanic isochrons: Earth and Planetary Science Letters, v. 196, p. 17-33, doi: 10.1016/S0012-821X(01)00588-X.

Van Calsteren, P.W.C., Boelrijk, N.A.I.M., Hebeda, E.H., Priem, H.N.A., Den Tex, E., Verdurmen, E.A.T.H., and Verschure, R.H., 1979, Isotopic dating of older elements (including the Cabo Ortegal mafic-ultramafic complex) in the Hercynian orogen of NW Spain: Manifestations of a presumed early Paleozoic mantle plume: Chemical Geology, v. 24, p. 35-56, doi: 10.1016/0009-2541(79)90011-1.

Van der Meer Mohr, C.G., 1975, The Palaeozoic strata near Moeche in Galicia: NW Spain: Leidse Geologische Mededelingen, v. 49, p. 32-37.

Vogel, D.E., 1967, Petrology of an eclogite- and pyrigarnite-bearing polymetamorphic rock complex at Cabo Ortegal: NW Spain: Leidse Geologische Mededelingen, v. 40, p. 121-213.

Von Raumer, J.F., and Neubauer, F., 1993, Late Precambrian and Paleozoic evolution of the Alpine basement-An overview, in Von Raumer, J.F., and Neubauer, F., eds., Pre-Mesozoic Geology in the Alps: Berlin, SpringerVerlag, p. 625-639. 